\title{
A survey of major law libraries around the world
}

\author{
David Gee *
}

The global development of legal information needs and services has continued to stimulate much professional discussion in recent years. This detailed report, and the comparative assessments and analysis it aims to provide, follow from one of the first global surveys of major law libraries around the world to take account of the present period of challenges and change. The report analyses the results of a comprehensive survey of 124 major law libraries world wide undertaken from April to June 2012 extending a methodology involving both quantitative and qualitative approaches which has proved successful in my previous research on the activities of law libraries across the UK. ${ }^{1}$ It is hoped that this comparative data and analysis (gathered from the activities, ambitions and concerns of law libraries in the real world) will provide a useful snapshot of current research support services, capture emerging trends and new service initiatives and encourage major law libraries to develop their services by providing helpful benchmarking and best practice information.

\section{Methodology}

The following report outlines the highlights and main trends in the provision of research support services in major law libraries around the world in 2012. The figures are taken from the results of a survey questionnaire distributed to major law libraries around the world between the end of April and mid-June 2012. The survey questionnaire was based on the survey templates created for the annual SLS/BIALL surveys of academic law libraries in the UK and Ireland, but significantly altered and extended to cover other areas of current law library activity. A copy of the circulated survey questionnaire is included in Appendix 1.

With the help of staff at the Institute of Advanced Legal Studies, I then created an upto-date list of major law libraries around the world complete with email and web contact details using the major foreign and international law libraries listed in Winterton and Moys's book as a starting point. ${ }^{2}$ Individually tailored emails promoting the survey and containing a link to the survey on the IALL website were sent to all the major law libraries on this list.

\footnotetext{
* David Gee, BA, MA, DipLib, MCLIP, CMgr MCMI has more than twenty years experience working in academic law libraries and legal information management and is currently Deputy Librarian and Academic Services Manager at the Institute of Advanced Legal Studies, School of Advanced Study in the University of London. He is a Chartered Manager of the Chartered Management Institute (CMI) and academic programme organiser for the IALS national training days on "How to get a PhD in law". He has been a member of the BIALL Council and a number of BIALL committees, a senior member of the Editorial Board of Legal Information Management, a founding Steering Group member of CPD25 (the training organisation of the M25 Consortium of Academic Libraries), a member-at-large of the IALL Scholarships Committee, a Visiting Fellow at the Max Planck Institute for Comparative and International Private Law, Hamburg, Germany and has written many articles for UK and international professional journals.

${ }^{1}$ David Gee, Society of Legal Scholars / BIALL Academic Law Library Survey 2010/2011, 12 (3) Legal Information Management, 218-232 (2012).

2 Jules Winterton and Elizabeth M. Moys (Eds.) Information sources in law. $2^{\text {nd }}$ ed. London: Bowker Saur, 1997.
} 
The International Association of Law Libraries Board was very supportive of my research and allowed me to post my survey questionnaire on the IALL website (www.iall.org) and to promote my survey to their members on their listserve. The survey was available in web format using SurveyMonkey, and a PDF of the questionnaire was also available on the first page in case respondents wished to print out the survey to work on whilst they gathered the data. IALL Board members also kindly posted and promoted my survey questionnaire on regional law library listserves to which they were members (e.g. the survey was promoted on the listserves of AALL FCIL-SIS, ALLA, ASIL International Research Group, BIALL, CALL, IFLA Law Libraries Section and NZLLA).

\section{Response rate}

In total I received 124 completed survey questionnaires, including 4 in paper format. I am very grateful to all those law librarians who took the time to respond. This response rate is very welcome and should permit the presentation of a reasonably accurate picture of major law libraries around the world.

The main reason given for non-returns was the length of the survey questionnaire which meant that some law librarians said they did not have the time to complete it. Also certain questions were not completed by all respondents as only the main library collected these statistics and the law librarian did not have access to this information or it was not possible to calculate the law library's proportion.

To help detect patterns in law library provision across the world, the data has been analysed using SPSS statistical software by both type of library and region:

\section{Type of library:}

University law school library (80 respondents)

Court library (10 respondents)

Law firm library (10 respondents)

Government department library (8 respondents)

Research institute library (6 respondents)

Bar / Law society library (4 respondents)

Other library (4 respondents)

Public library (2 respondents)

\section{Region:}

Europe (53 respondents)

North America (32 respondents)

Africa (13 respondents)

Australia and New Zealand (10 respondents)

Asia (9 respondents)

Middle East (4 respondents)

Central and South America (3 respondents)

A list of all the names of the major law libraries that completed the survey questionnaire is available in Appendix 2.

To keep the report within a reasonable length, I will mainly outline the key findings and not provide statistics and analysis for every type of library and every region in every case. However I will occasionally highlight more detailed statistics when the samples are statistically large enough to be useful and when I think law librarians will find the conclusions interesting. I should point out that as the statistical samples for "Public libraries" and "Other libraries" are so small, it has not proved possible to calculate meaningful results for these two groups in much of the report (although 
their data is always included in the calculations for the overall and regional results and their comments are included in the appendices). In addition for the same reason of small statistical samples the results for type of library by region are usually limited to just the results for university law school libraries by region.

\section{Definitions}

In many of the following sections the survey responses are analysed using range, mean and median.

- The range indicates the smallest and the greatest value of the responses and helps us understand the diversity of responses.

- The mean has been calculated by adding up all the resources and dividing by the number of responses to get an "average". The mean can be distorted by one or two responses which are very large or very small.

- The median is the mid point and is calculated through ordering the responses by size from the smallest to the greatest and finding the middle response. There will be an equal number of responses below the median and above the median and so it provides a benchmark of what a "typical" library is doing.

All numbers and percentages have been rounded to the nearest whole number.

All of the eleven report appendices are conveniently listed at the end of this article and their contents are permanently accessible on the following IALS webpage: http://ials.sas.ac.uk/library/lawlibs/report.htm

\section{Summary of key findings}

- The highest average number of patrons was in Bar / Law society libraries with a mean of 4,450 , whilst the lowest average number of patrons was in law firm libraries with a mean of 521 (section 1);

- The majority of libraries were located in a single law library separated from other subject collections (61\%), whilst $20 \%$ had a law collection not so separated but shelved so as to form a single identifiable unit (e.g. a whole floor), 15\% had several law collections each in a different location, and $4 \%$ had a law collection dispersed among other subject collections (section 2);

- The lowest (and most generous) patrons to seats ratio was for university law school libraries at 7:1. The highest (and least generous) patrons to seats ratio was for Court libraries at 103:1 (section 3.1);

- A large majority of libraries (80.5\%) confirmed that they did provide WiFi for patrons (section 3.3);

- The average number of hours during a term-time week when a staffed book circulation service was available for law items was 72 hours (section 4.1);

- Surprisingly a large majority of libraries (70\%) did not provide a self-check-out machine for circulating items from the law collection (section 4.2);

- The highest average number of term-time weekly opening hours when a professional law librarian was staffing a reader enquiry service for law was for Bar / Law society libraries with a mean of 64 hours. The lowest average number of term-time weekly opening hours when a professional law librarian was staffing 
a reader enquiry service for law was for Court libraries with 43 hours (section 4.3);

- The three types of library with the highest average number of printed volumes were university law school libraries with a mean of 274,740 volumes, research institute libraries with a mean of 254,349 and government department libraries with a mean of 248,992 volumes (section 5.1 );

- The highest average number of electronic databases received by subscription was for university law school libraries with a mean of 172 subscription databases (section 5.2);

- The three most popular subscription databases were Westlaw (mentioned by 83 libraries), Lexis (mentioned by 78 libraries) and HeinOnline (mentioned by 55 libraries) (section 6);

- A list of all the cancelled legal databases with the reasons for cancellation is provided by type of library (section 7);

- A useful comparative snapshot of all the digitisation projects undertaken by major law libraries across the world is provided by type of library (section 8);

- A list of weblinks to the special collections and archives of major law libraries is provided by type of library (section 9);

- The average split of library collections was $57 \%$ for national materials, $25 \%$ for foreign and comparative materials and $18 \%$ for international materials. But these overall averages, disguised very wide variations by type of library and region (section 10);

- The highest average annual expenditure on print law materials was in Court libraries with a mean of US\$1,165,961 (section 11.2);

- The highest average annual expenditure on electronic law materials was in law firm libraries with a mean of US\$480,122 (section 11.3);

- In most Court libraries, research institute libraries, Bar / Law society libraries and university law school libraries, the majority of annual acquisitions budgets were spent on print materials. Alternatively in most government department libraries and law firm libraries, the majority of annual acquisitions budgets were spent on electronic materials (section 11);

- The highest average number of staff was found in government department libraries with a mean FTE of 48.14 staff (section 12.1);

- A list of the training and staff development opportunities offered by libraries for their library staff is provided by type of library (section 13);

- Overall $87 \%$ of libraries confirmed that they provided some form of legal research skills training (section 14.1);

- Impressively all university law school library respondents in North America, Europe, Central and South America, Australia and New Zealand, and Asia provided legal research skills training. $75 \%$ of university law school libraries in the 
Middle East provided this training and $62.5 \%$ of university law school libraries in Africa provided legal research skills training (section 14.1);

- Library staff were the most significant trainers in legal research skills in major law libraries around the world, with external trainers and law school lecturing staff generally far less involved and Lexis Student Associates and other staff even less involved (section 14.2);

- Court libraries had the highest average number of contact training hours with patrons with an average of 257 hours a year (section 14.4);

- The three most popular training delivery methods in libraries around the world in order of popularity were the lecture, the IT workshop and the tutorial (section 14.5);

- Libraries were least likely to be involved in some role with their institutional VLE, whilst they were most likely to be involved in some way with their Library Management System and the content and design of their law library webpages (section 15);

- In the majority of libraries (i.e. in 52\%), library staff wrote and published professional articles. By type of library, library staff were most likely to write and publish professional articles in research institute libraries (section 16.1);

- In the overwhelming majority of libraries (i.e. in 91\%), library staff contributed to subject and research guides. By type of library, library staff were most likely to contribute to subject and research guides in law firms libraries (section 16.2);

- In the majority of libraries (i.e. in 55\%), library staff contributed to other information sources such as web portals or gateways for their patrons. By type of library, library staff were most likely to contribute to web portals or gateways in government department libraries (section 16.3);

- The most popular Library Management System used by major law libraries around the world was Millennium supplied by Innovative Interfaces Inc. (section $17)$;

- Libraries were least likely to be involved in some way with the library's social networking sites, whilst they were most likely to be involved in some role with the regular emailing of information to patrons (section 18);

- In the majority of libraries (i.e. in 63\%), tailored services of some kind were offered to different patron groups. By type of library, research institute libraries were most likely to offer these specialised services (section 19);

- The three most important ambitions for university law school libraries were (in order of priority) to develop the library's electronic and digital resources, to improve research skills training for patrons and to refurbish and better use library space to provide new patron services (section 20).

\section{Findings in detail}

This part of the report sets out the findings in detail drawn from the answers given by respondents to each of the questions that formed the survey questionnaire. The sections below correspond to the broad question areas featured in the survey. 


\section{Number of patrons}

A representation of the number of library patrons served by the major law libraries helps in understanding the framework in which provision is made and can assist librarians in comparing their provision with libraries of similar types and regions. Respondents were asked to indicate the total number of patrons enrolled at their library in 2010/2011. 121 out of 124 respondents or $98 \%$ answered this question. The overall range across all library types and all regions was 32-50,000 (libraries with an automatic national membership have been temporarily excluded) and the overall mean was 3,504 and the median was 1,103.

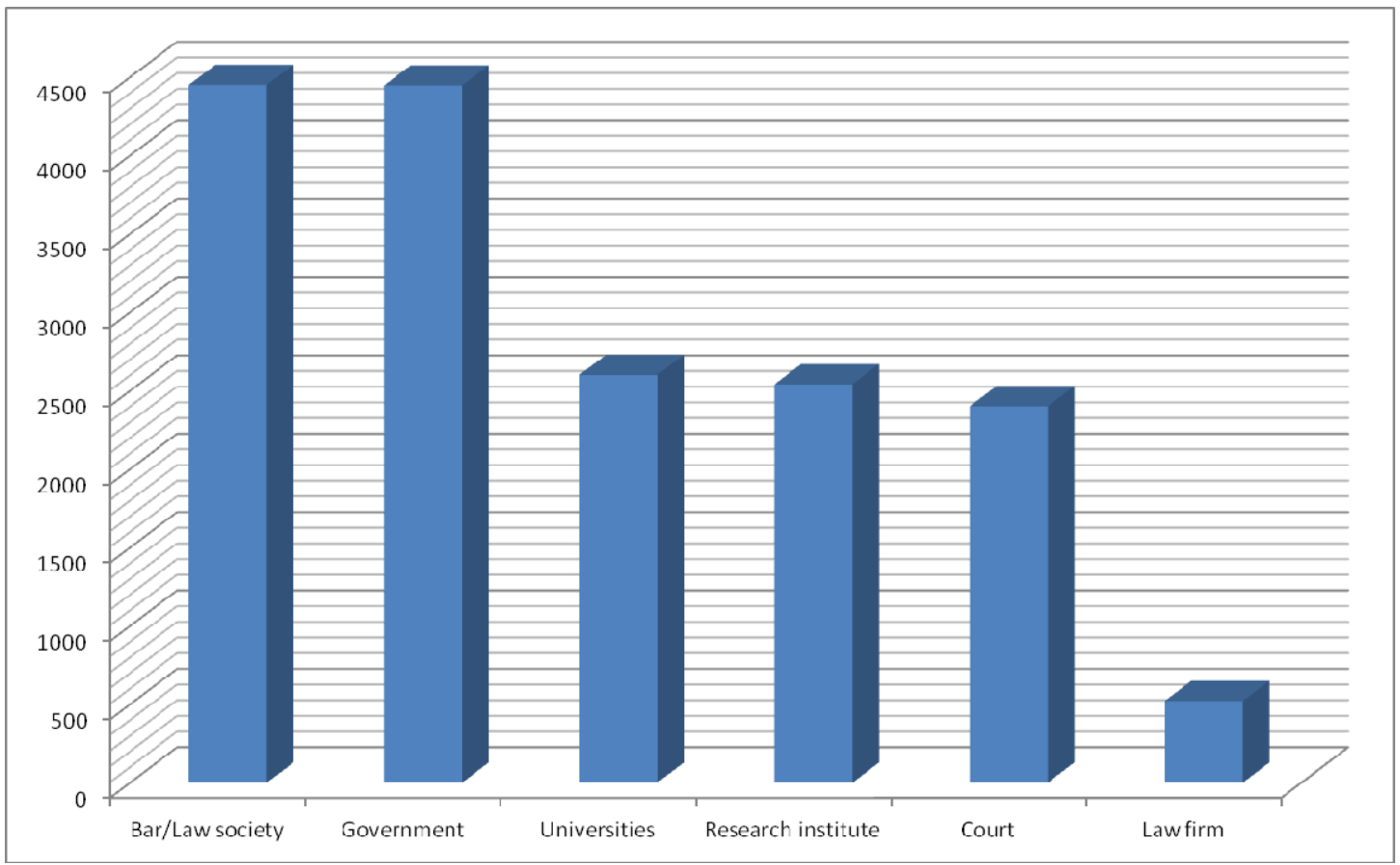

Graph 1: Average number of patrons served by major law libraries around the world

As the above graph shows, the highest means were for Bar / Law society libraries and government departmental libraries with 4,450 and 4,446 respectively. The means in university law school libraries, research institute libraries and court libraries were similar at 2,600, 2,541 and 2,400. The lowest mean was for law firm libraries which was only 521.

By region, Europe had the highest mean at 5,116. Africa was 2,899, Asia was 2,876, Australia and New Zealand was 2,696 and North America was 2,118. The lowest means were for Middle East with 1,350 and Central and South America at 781.

If one compares university law school libraries in different regions, the highest mean was for universities in Africa at 4,425. This was followed by the means for universities in Europe $(3,618)$, Asia $(3,552)$, Australia and New Zealand $(2,233)$ and the Middle East $(1,350)$. The lowest mean of 1,229 was for universities in North America.

\section{Location of library}

Respondents were asked to indicate from a list of four options which most closely matched the location of their library. All 124 respondents answered this question. 


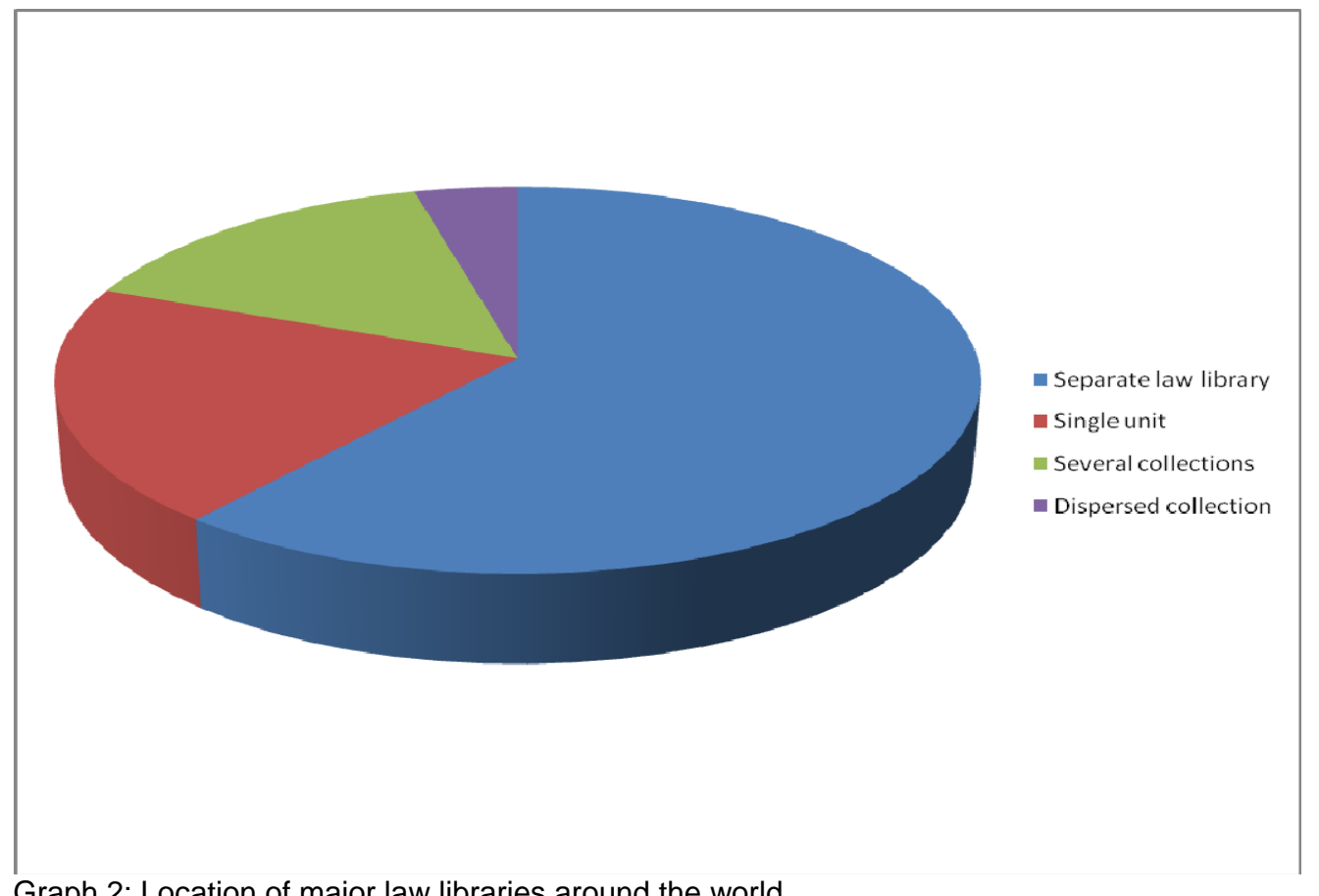

Graph 2: Location of major law libraries around the world

As the above pie chart demonstrates, across all law library types and regions:

- $61 \%$ had a single law library in a location separated from other subject collections.

- $20 \%$ had a law collection not so separated but shelved so as to form a single identifiable unit (e.g. a whole floor).

- $15 \%$ had several law collections each in a different location.

- $4 \%$ had a law collection dispersed among other subject collections.

By type of library the most popular category describing the location of a law library was also the first category listed above: a single law library in a location separated from other subject collections (although please note that in Court libraries this first category tied in first place with the third category). It appears that this was the trend in most regions and in most university law school libraries within regions. The only exceptions were in Middle Eastern libraries generally and in Middle Eastern university law school libraries where the most popular category describing the location of a law library was: a law collection not so separated, but shelved to form a single unit.

\section{Conclusions}

In general, these figures strongly suggest that major law libraries across the world were doing much better than other subject collections in defending their separateness within general libraries, with the probability that the law collection was either housed in its own library building or was located in a distinct area or floor within the institution. This conclusion fits in well with various published national standards for law libraries. For example in the UK the comments to the Society of Legal Scholars Statement of Standards 3.1 on space and physical facilities require "the housing of all relevant collections... as a unified whole in one place...". 3

\footnotetext{
${ }^{3}$ Society of Legal Scholars (2009) A library for the modern law school. A statement of standards for university law library provision in the United Kingdom - 2009 revision. Available at http://www.legalscholars.ac.uk/documents/SLS-Library-for-a-Modern-Law-SchoolStatement-2009.pdf
} 


\section{Study facilities}

In order to be able to report on the comparative study facilities in libraries around the world, respondents were asked questions on the provision of seating, PC or Mac workstations and WiFi for their patrons.

\subsection{Provision of seats}

Respondents were asked to indicate the number of seats in study areas by the law collection(s), excluding computer workstations. 116 libraries or $93.5 \%$ of respondents provided figures. The figures ranged from 1 to 2,864 seats with an overall mean of 273 and a median of 173 . The results must be viewed with some caution however. As has been noted in section 2 above, there is a significant number of institutions where the law collection is not separate from other subjects, and respondents have taken different views on how to count the amount of seating which was "by the law collection" as required in the survey question.

A more useful measure is the ratio of patrons to seats. 114 of the 116 responding libraries were able to provide data for both variables. The overall patrons to seats ratio was 13:1.

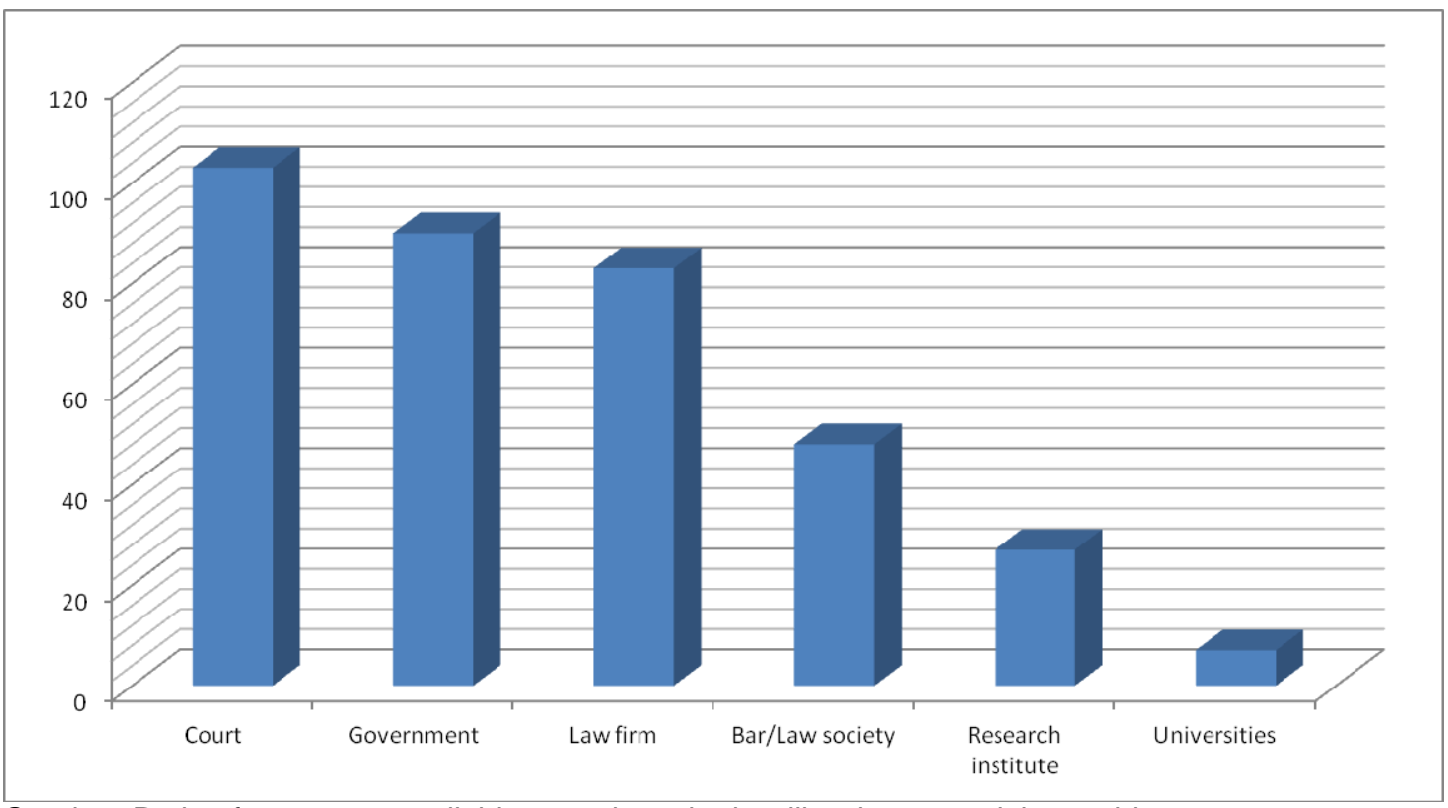

Graph 3: Ratio of patrons to available seats in major law libraries around the world

As the above graph shows, the highest (and least generous) patrons to seats ratio was for Court libraries at 103:1, followed by government department libraries at 90:1, law firm libraries at 83:1, Bar / Law Society libraries at 48:1 and research institute libraries at 27:1. The lowest (and most generous) patrons to seats ratio was for university law school libraries at 7:1.

By region the highest (and least generous) patrons to seats ratios were for Europe at $21: 1$ and Australia and New Zealand at 20:1. The other regional ratios were fairly similar with Africa at 17:1, Asia at 16:1 and the Middle East at 15:1. The lowest (and most generous) patrons to seats ratios were for North America at 5:1 and Central and South America at 4:1.

If one compares university law school libraries in different regions, the highest (and least generous) patrons to seats ratio was for university law school libraries in Africa with 18:1. This was followed by universities in Asia and the Middle East with 15:1 a piece. The patrons to seats ratios for university law school libraries in Europe was 9:1 
and in Australia and New Zealand it was 7:1. The lowest (and most generous) patrons to seats ratios were 3:1 for university law school libraries in North America and 2:1 for universities in Central and South America.

\subsection{Provision of PC or Mac workstations}

The survey asked respondents to indicate the number of PC or Mac workstations which can access electronic law materials and are available for patron use. 117 libraries or $94 \%$ of respondents provided figures. The figures ranged from 1 to 4,000 workstations with a mean of 93 and a median of 27. Again these results must be viewed with some caution, so I have used the measure of patrons to PC or Mac workstations to give a more effective picture of the levels of provision.

115 of the 117 responding libraries were able to provide data for both variables. The overall patrons to workstations ratio was 38:1. By type of library the lowest (and most generous) patrons to workstations ratio was for Court libraries at 5:1, followed by law firm libraries at 11:1, university law school libraries at 36:1 and research Institute libraries at 48:1. The highest (and least generous) patrons to workstations ratios were for Bar / Law society libraries at 209:1 and government departmental libraries at 247:1.

By region the lowest (and most generous) patrons to workstations ratio was for Australia and New Zealand at 6:1. The other regional ratios were similar with the Middle East at 33:1, Central and South America at 36:1, Africa at 56:1, Asia at 57:1 and Europe at 58:1. The highest (and least generous) patrons to workstations ratio was for North America with 75:1.

If one compares university law school libraries in different regions, the lowest (and most generous) patrons to workstations ratio of 28:1 was for universities in Europe, followed by universities in Australia and New Zealand at 31:1 and universities in the Middle East and Central and South America with 33:1 each. The patrons to workstations ratio in universities in North America was 43:1, in Asia was 55:1 and in Africa was 58:1.

It is interesting to compare the trends for seats and workstations. For example, whereas Court libraries were the least generous in terms of patrons to seats (103:1), they were the most generous in terms of patrons to PC or Mac workstations (5:1). Part of the answer may be that Court libraries were responsible for all PC or Mac workstations in the whole building (rather than just in the library) as they had responsibility for legal database licences and other support functions.

\subsection{Provision of WiFi}

The survey asked if WiFi access to law databases was available within the library. 123 libraries or $99 \%$ of respondents provided figures. $80.5 \%$ of respondents confirmed that they did provide WiFi with only $19.5 \%$ saying that they did not provide WiFi. By type of library this general trend of a large majority of libraries providing WiFi was also found in university law school libraries (with 94\% providing this service), research institute libraries (with 100\% providing this service) and law firm libraries (with 70\% providing this service). However in Court libraries and in governmental department libraries the majority of respondents did not provide WiFi. In Bar / Law society libraries the figures are equal with half the libraries providing the service and the other half not offering this service.

Interestingly in almost all regional categories the majority of libraries provided WiFi for their patrons. The one regional exception was in Australia and New Zealand where two thirds of the respondents did not provide WiFi. 
This general trend of a majority of libraries providing WiFi for their users is also the case for university law school libraries within every regional category.

\section{Opening hours}

To help provide useful indications of the opening hours of major law libraries around the world, the survey asked questions on the provision of a staffed book circulation service for law items, the availability of a self-check-out machine for circulating items from the law collection and the number of hours a week that a professional law librarian staffed a reader enquiry service for law.

\subsection{Staffed book circulation service available for law items}

Respondents were asked to report on the numbers of hours during a term-time week when a staffed book circulation service was available for law items. 109 libraries or $88 \%$ of respondents provided figures. The overall mean was 72 hours, the overall median was 73 hours and the overall range was from 30 hours to 113 hours per term-time week.

By type of library, the highest average number of term-time weekly opening hours when a staffed book circulation service was available for law items was for university law school libraries with a mean of 81 hours. This was followed by Bar / Law society libraries with 67 hours, research institute libraries with 62 hours, Court libraries with 48 hours, governmental department libraries with 45 hours and law firm libraries with 38 hours.

By region, the highest average number of term-time weekly opening hours when a staffed book circulation service was available for law items was for North America with a mean of 94 hours. This was followed by Central and South America with 75 hours, Africa with 71 hours, Asia with 63 hours, Europe with 62 hours, the Middle East with 56 hours and Australia and New Zealand with 54 hours.

\subsection{Self-check-out machine for circulating items from the law collection} The survey asked whether respondents provided a self-check-out machine for circulating items from the law collection. 123 libraries or $99 \%$ of respondents provided this information. Surprisingly overall $70 \%$ of these respondents did not provide this service. By type of library, most libraries did not offer self-check-out machines. For example in university law school libraries, 54 libraries or $68 \%$ of respondents did not offer this service. Similarly, by region most libraries did not offer self-check-out machines. For example in North America 26 libraries or $81 \%$ of respondents did not offer this service.

If one compares university law school libraries in different regions, the only region where the majority of university law school libraries offered this service was in Europe (with 59\%). In all other regions there were large majorities of university law school libraries not providing this service.

\section{Conclusions}

These findings show that most major law libraries did not think it necessary to offer this service to their patrons. It may be that most were keen (and could continue to afford) to preserve the value added by personal interaction with librarians staffing their circulation desk. In addition, it was also the case that some major law libraries were reference only and did not offer a book circulating system at all. 


\subsection{Professional law librarians staffing reader enquiry service for law}

114 libraries or $92 \%$ of respondents reported on how many hours a week in term time their enquiry/reference service was staffed by professional law librarians. Hours when professional staff could only offer a service of referral onto a law specialist are excluded. The overall mean was 49 hours per term-time week, the overall median was 44.5 hours and the overall range was from 4 hours to 168 hours (or 24/7) per term-time week.

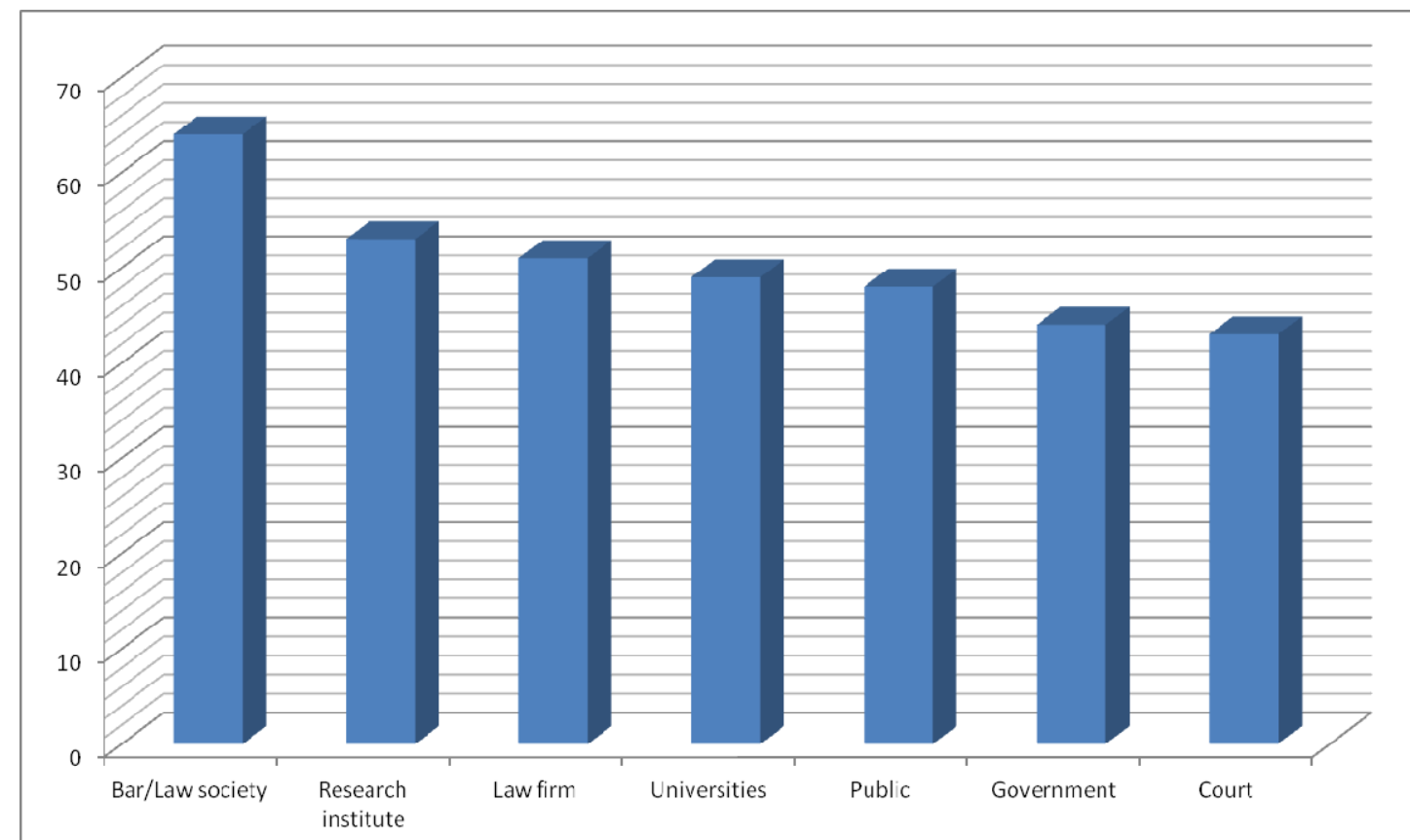

Graph 4: Average number of weekly opening hours when a reader enquiry point for law was available in major law libraries around the world

As the above graph shows, by type of library the highest average number of term time weekly opening hours when a professional law librarian was staffing a reader enquiry service for law was for Bar / Law society libraries with a mean of 64 hours. This was followed by research institute libraries with 53 hours, law firm libraries with 51 hours, university law school libraries with 49 hours, public law libraries with 48 hours, government department libraries with 44 hours and Court libraries with 43 hours.

By region, the highest average number of term-time weekly opening hours when a professional law librarian was staffing a reader enquiry service for law was for Central and South America with 60 hours. This was followed by North America with 59 hours, Africa with 48 hours, Europe with 45 hours, Australia and New Zealand and the Middle East both with 44 hours and Asia with 38 hours.

If one compares university law school libraries, in North America the mean was 55 hours (from a sample of 30 respondents) whilst in Europe it was surprisingly much lower with only 39 hours (from a sample of 26 libraries). Average term time weekly opening hours when a law librarian was staffing a reader enquiry service for law was therefore much higher in North American university law school libraries than in European university law school libraries. 


\section{Collections}

Respondents were asked to report on their collections to give a helpful indication of the average size and particular focus, by type and region, of major law libraries around the world.

\subsection{Printed volumes}

111 libraries or $89.5 \%$ of respondents reported on the total number of printed volumes in their law library. The overall mean was 249,954 volumes, the overall median was 112,000 and the overall range was from 500 to 1,800,000 volumes.

By type of library, the three types of library with the highest average number of printed volumes were university law school libraries with a mean of 274,740 volumes, research institute libraries with a mean of 254,349 volumes and government department libraries with a mean of 248,992 volumes. This group was followed by Court libraries with a mean of 94,063 volumes, Bar / Law society libraries with a mean of 76,667 and law firm libraries with a mean of only 5,675 volumes.

By region, North American libraries had by far the highest average number of printed volumes in their collections with a mean of 563,433 . This was followed by a group of three regions: Central and South America with a mean of 189,069 volumes, Europe with a mean of 184,399 volumes and Australia and New Zealand with a mean of 123,751 volumes. Asian libraries had a mean of 60,536 volumes, Middle Eastern libraries had a mean of 32,400 volumes and lastly African libraries had a mean of 26,028 volumes.

If one compares university law school libraries in different regions, it is clear that university law school libraries in North America had by far the largest average number of printed volumes at 548,378, whereas those in the Middle East and Africa had the lowest means at 32,400 and 31,218 volumes respectively.

\subsection{Subscription databases}

106 libraries or $85.5 \%$ of respondents reported on the number of electronic databases received by subscription in their law library. The overall mean was 124 databases, the median was 25 and the overall range was 1 to 6,000 databases.

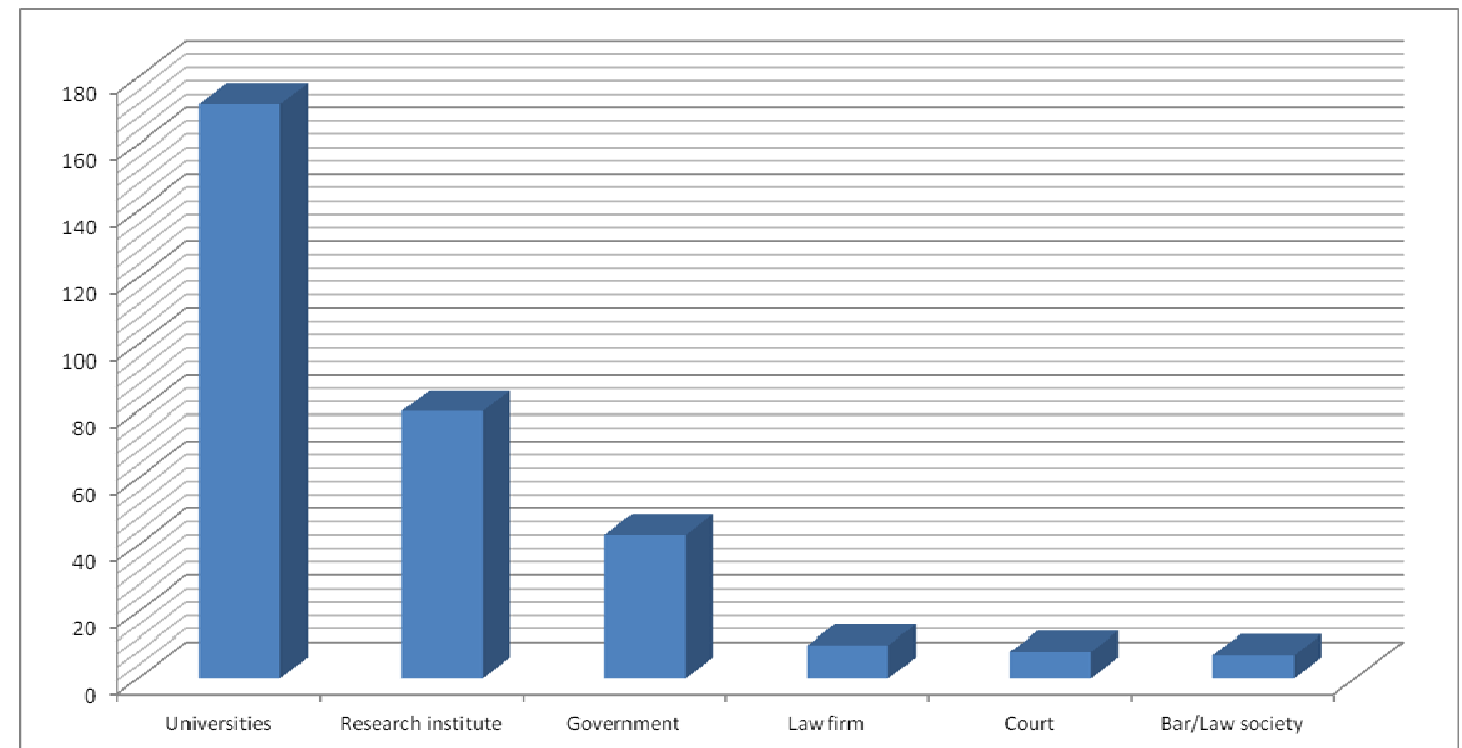

Graph 5: Average number of subscription databases available to patrons in major law libraries around the world 
As the above graph shows, by type of library the highest average number was for university law school libraries with a mean of 172 subscription databases. This was followed by research institute libraries with a mean of 80 and government department libraries with a mean of 43 . Law firm libraries had a mean of 10 , Court libraries had a mean of 8 and Bar / Law society libraries had a mean of 7 databases.

By region, North American libraries had by far the highest average number of subscription databases with a mean of 302. This was followed by Australian and New Zealand libraries with a mean of 150 databases. European libraries had a mean of 81, Middle Eastern libraries had a mean of 34, African libraries had a mean of 32 and Asian libraries had a mean of only 18 databases.

If one compares university law school libraries in different regions, it is clear that university law schools in North America had by far the largest mean number of databases at 327 (although please note that one very high responses of 6,000 inflated this average). This was followed by university law schools in Australia and New Zealand with a mean number of 295 databases (although again one very high response of 800 inflated this average). University law schools in Europe had a mean of 114 databases, those in Africa had a mean of 50 databases (although one very high response of 260 inflated this average), those in the Middle East had a mean of 34 databases and those in Asia had a mean of 22 databases. University law school libraries in Central and South America had the lowest mean number with 11 databases.

\section{Most popular subscription databases}

109 libraries or $88 \%$ of respondents identified and listed in order their three most popular subscription databases. In overall terms, across all types of library and all regions, the ten most frequently mentioned subscription databases are displayed in the following graph:

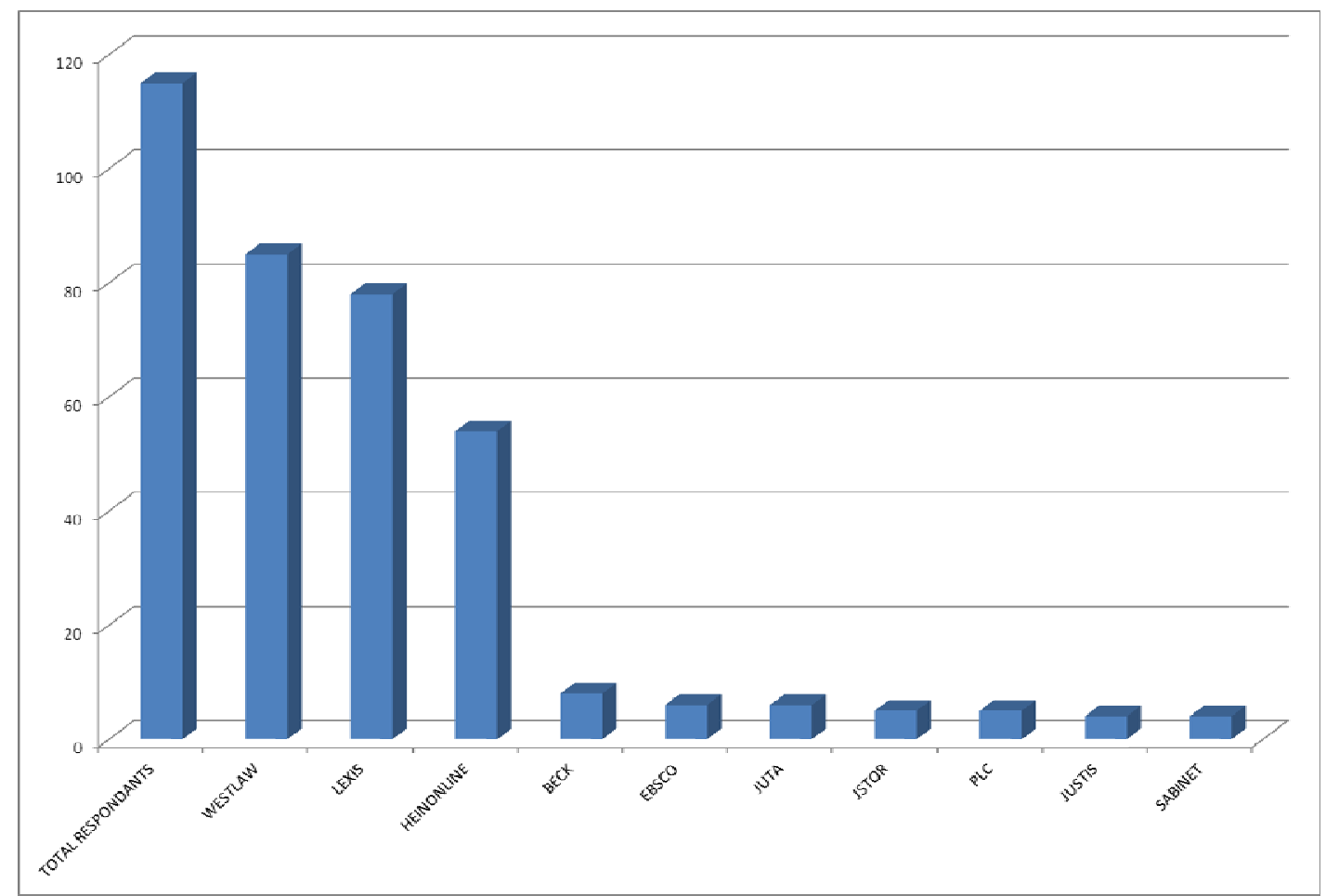

Graph 6: Top ten most popular online databases subscribed to by major law libraries around the world 
As the above graph shows, the three most frequently mentioned databases were Westlaw (mentioned by 83 libraries), Lexis (mentioned by 78 libraries) and HeinOnline (mentioned by 55 libraries). These top three easily dominated the subscription databases market across all major law libraries across the world. They are followed some considerable way behind by Beck Online, EBSCO and Juta (all mentioned by 6 libraries). JSTOR and PLC were both mentioned by 5 libraries and Justis and Sabinet were both mentioned by 4 libraries. All other subscription databases are mentioned by only 3 libraries or fewer.

Full details and additional graphs showing the variation in the most popular subscription databases by type of library and by region are contained in Appendix 3 . A summary of the key points is outlined below. These particular statistics and the analysis should provide useful benchmarking information for libraries.

\subsection{By type of library:}

\section{University law school libraries}

The same top three subscription databases dominated University law school libraries. Westlaw was mentioned by 59 libraries, Lexis by 55 libraries and HeinOnline by 42 libraries. Next came JSTOR and Juta (both mentioned by 4 libraries), Dalloz and EBSCO (both mentioned by 3 libraries) and Jura, Kluwer, Sabinet, Juris, Projectmuse and Proquest all mentioned by 2 libraries. The other 43 subscription databases were mentioned only once.

\section{Research institute libraries}

The top three most popular subscription databases changed to HeinOnline (mentioned by 5 libraries), Beck Online (mentioned by 4 libraries) and Lexis (mentioned by 3 libraries). Westlaw was mentioned by 2 libraries and Law Pavilion and Juris were mentioned by one library each.

\section{Court libraries}

The top three most popular databases changed to Lexis (mentioned by 7 libraries), Westlaw (mentioned by 6 libraries) and Thompson Reuteurs (mentioned by 4 libraries). HeinOnline was mentioned by 2 libraries. The other 9 databases were mentioned only once.

\section{Government department libraries}

Westlaw was mentioned by 3 libraries. The other 15 subscription databases were mentioned only once.

\section{Law firm libraries}

The top three databases were Lexis (mentioned by 7 libraries), Westlaw (mentioned by 6 libraries) and PLC (mentioned by 3 libraries). The other 5 subscription databases were mentioned only once.

\section{Bar I Law society libraries}

Lexis and Westlaw were both mentioned by 3 libraries and Justis was mentioned by 2 libraries. The other 3 databases were mentioned only once.

\section{Public libraries and Other libraries}

The top two subscription databases were HeinOnline and Westlaw which were both mentioned by 4 libraries each. Lexis was mentioned by 2 libraries. The other 8 databases were mentioned only once. 


\section{Some conclusions}

By type of library, Westlaw, Lexis and HeinOnline dominated the subscription databases market across all types of library. However their dominance was not complete as each of them failed to enter the top three most popular databases in at least one "type of library" category. Even Westlaw which was in the top three most popular databases for most types of library, was only the fourth most popular database in research institute libraries.

\subsection{By region:}

\section{African libraries}

The top three subscription databases were Juta and Lexis (both mentioned by 6 libraries), Sabinet (mentioned by 4 libraries) and JSTOR, Uganda online law library, and Westlaw (mentioned by 2 libraries each). The other 9 databases were mentioned only once.

\section{North American libraries}

The joint top three subscription databases were HeinOnline, Lexis and Westlaw (surprisingly each was mentioned by 28 libraries). The other 9 databases were mentioned only once.

\section{Central and South American libraries}

The top subscription databases were Microjuris and Westlaw (both mentioned by 2 libraries) and Lexis and Legal Publishing Hile (both mentioned by one library).

\section{Australian and New Zealand libraries}

Lexis was mentioned by 7 libraries, Westlaw was mentioned by 4 libraries and Thomson Reuteurs was mentioned by 3 libraries. Bookers Online, Legal Online and Firstpoint were each mentioned by 2 libraries. The other 8 databases were mentioned only once.

\section{Middle Eastern libraries}

The joint top three subscription databases were Dalloz, Westlaw International and Lexis (each mentioned by 2 libraries). The other 6 databases were mentioned only once.

\section{European libraries}

The top three subscription databases were Westlaw (mentioned by 39 libraries), Lexis (mentioned by 27 libraries) and HeinOnline (mentioned by 21 libraries). Beck Online was mentioned by 6 libraries, EBSCO was mentioned by 5 libraries and Juris, Justis and PLC were mentioned by 4 libraries each. Kluwer, JSTOR and Lawtel were mentioned by 2 libraries each. The other 27 databases were mentioned only once.

\section{Asian libraries}

The most popular subscription databases were Westlaw (mentioned by 6 libraries), HeinOnline and Lexis (both mentioned by 4 libraries) and SCC Online (mentioned by 2 libraries). The other 8 databases were mentioned only once.

\section{Some conclusions}

By region, again Westlaw and Lexis dominated the subscription databases market. However again their dominance was not complete as each failed to enter the top three most popular databases in one regional category. Westlaw was not in the top three in the "African libraries" region and Lexis was not in the top three in the "Central and South American" region. HeinOnline was less frequently mentioned across the regional categories than it had been across the type of library categories. 
Nevertheless it was in the top three most popular databases in three of the seven regional categories.

\section{List of cancelled databases}

The questionnaire asked respondents to identify any key databases which were cancelled in 2010/2011 and to give the reasons. A full list of cancellation titles by type of library is provided in Appendix 4. The database titles cancelled vary by type of library, but Kluwer Law International and Justis products were mentioned in three different categories and Lexis was mentioned in two categories. The main reason given for cancelling databases was budget constraints. Duplication with other sources and lack of use were also mentioned as reasons for cancelling, but much less frequently.

\section{Library involvement with digitisation projects}

In order to provide a useful comparative snapshot of the digitisation projects which were being undertaken by major law libraries across the world, the survey asked respondents to list and describe any digitisation projects in which they were involved. Full details including weblinks are available in Appendix 5. A summary of the findings is provided below.

- 29 university law school libraries (out of a total of 80 ) listed the digitisation projects in which they managed or participated. Most of these libraries were only involved with one project, but five libraries were involved in two projects and one library in Canada listed involvement in four digitisation projects. The subject for digitisation varied greatly, but digitisation of local unique historical materials, local material for inclusion in LLMC Digital, local law reviews and local theses were mentioned more than once.

- 4 government department libraries (out of a total of 8) were involved in digitisation projects. These included projects to digitise newspapers, historical laws and parliamentary records.

- 4 Court libraries (out of a total of 10) were involved in digitisation projects. These included digitising older legislation and unreported judgments as well as court photographs and ceremonial speeches.

- 3 Other libraries (out of a total of 4 ) were involved with digitisation projects. The materials to be digitised ranged from Peace Movement and Tokyo Tribunal materials to legal gazettes and private papers.

- 2 Public libraries (out of a total of 2) were involved with a digitisation project. The projects included scanning California Appellate Briefs received from court.

- 2 research institute libraries (out of a total of 6) listed digitisation projects in which they were involved. One of these was involvement with the LLMC Common Law Abroad project.

- Only 1 law firm library (out of a total of 10 ) was involved with a digitisation project. This was digitising old authorities and precedents for in-house use only.

- Only 1 Bar / Law society library (out of a total of 4) was involved with a digitisation project. This was digitising rare books.

\section{Library special collections: weblinks}

Libraries were asked to provide weblinks to any special collections or archives and manuscripts for which they were responsible. A full list by type of library is available in Appendix 6. 


\section{Proportion of national, foreign and comparative, and international materials in collections}

The survey asked libraries to estimate how much of their collections are made up of national legal materials, foreign and comparative legal materials, and international legal materials. 103 libraries or $83 \%$ of respondents reported on this estimated percentage split.

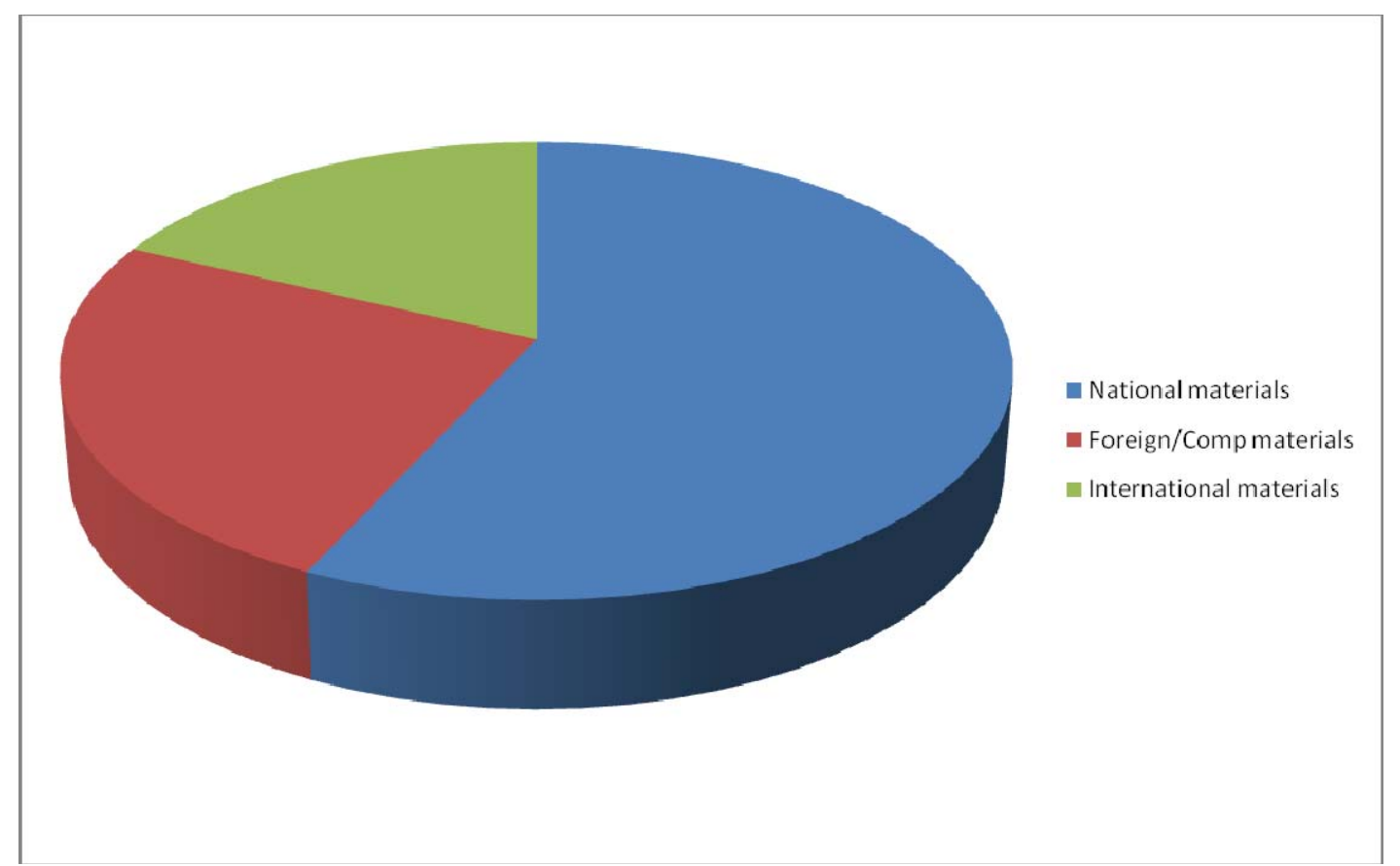

Graph 7: Average proportion of national materials, foreign and comparative materials and international materials in the collections of major law libraries around the world

As the above graph shows, on average the overall split was $57 \%$ for national materials, $25 \%$ for foreign and comparative materials and $18 \%$ for international materials. But these overall averages, disguised very wide variations by type of library and region.

\section{National legal materials}

By type of library, law firm libraries had the highest average percentage for national materials with $73 \%$, followed by government department libraries at $71 \%$, Court libraries at $61 \%$, university law school libraries at $58 \%$ and Bar / Law society libraries at $47 \%$. Research institute libraries had the lowest average percentage at $18 \%$.

By region, libraries in Central and South America had the highest average percentage of national materials at $87 \%$, followed by North American and Australian and New Zealand libraries both with 66\%. European libraries had 53\%, Asian libraries had $47 \%$, African libraries had $45 \%$ and Middle Eastern libraries had only $40 \%$ of their collections which they categorised as national materials.

\section{Foreign and comparative legal materials}

By type of library, the order is quite different with the highest average percentage for research institute libraries at $61 \%$ and for Bar / Law society libraries at $43 \%$. Other types of library are clustered together around an average of $20 \%$ with law firm libraries with the lowest percentage at $13 \%$.

By region, the average percentages are generally lower with Asia being the highest average at $34 \%$. Followed by Africa at 32\%, Middle East at 30\%, Europe at 27\%, 
North America and Australia and New Zealand with 21\% a piece and Central and South America at $11 \%$.

\section{International legal materials}

By type of library, all the percentages are much lower than in the other categories of materials with research institute libraries highest at $21 \%$, followed by university law school libraries at $18 \%$, law firm libraries at $14 \%$, Court libraries at $13 \%$, government department libraries at $11 \%$ and Bar / Law society libraries at $10 \%$.

By region, again all the percentages are lower than in the other categories of materials with Middle Eastern libraries at 30\%, African libraries at 23\%, European libraries at $20 \%$ and Asian libraries at $19 \%$. Interesting both North American and Australian and New Zealand libraries had only 13\% each, whilst Central and South American libraries had only an average of $2 \%$ of their collections which they categorised as international materials.

\section{Expenditure on law materials}

96 libraries or $77.4 \%$ of respondents were able to provide total expenditure figures on law materials for the year 2010/2011. All expenditure figures have been converted into US dollars for ease of comparison.

\subsection{Total expenditure on law materials}

Total expenditure in $2010 / 2011$ on the acquisition of law materials in major law libraries around the world ranged from US $\$ 4,679$ to US $\$ 4,447,630$. The overall mean expenditure was US\$872,012 and the median was US\$609,492.

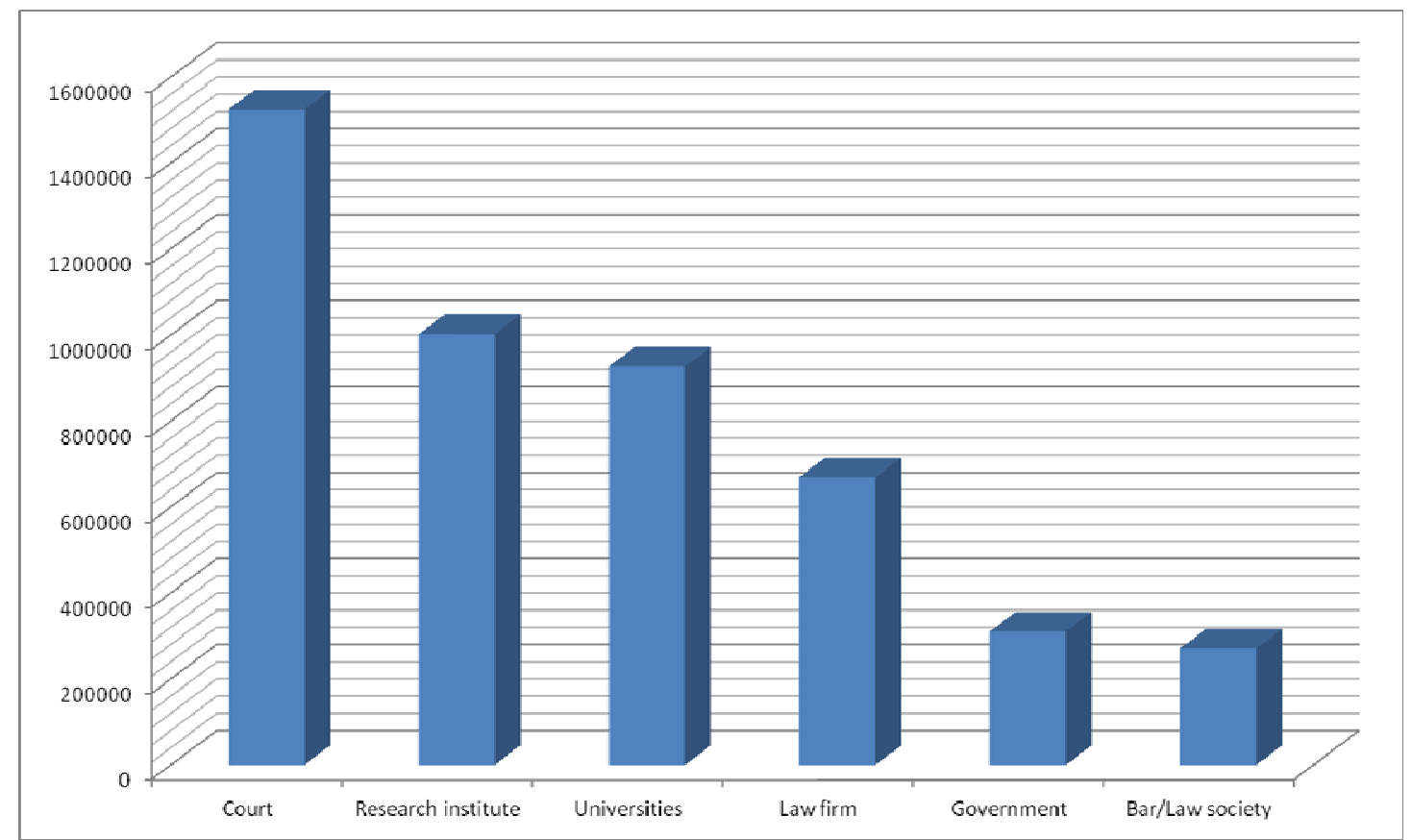

Graph 8: Average annual spend in US dollars on law materials in major law libraries around the world

As the above graph shows, by type of library the highest average annual expenditure was in Court libraries with a mean of US $\$ 1,523,939$. This was followed by research institute libraries with a mean of US\$1,001,795 and university law school libraries with a mean of US\$926,912. Law firm libraries had a mean of US\$669,257 and government department libraries had a mean of US\$310,460. The lowest average expenditure on law materials was in Bar / Law society libraries with a mean of US\$270,523. 
By region, the two highest average annual expenditures on law materials by far were in North American libraries with a mean of US\$1,736,052 and in Australian and New Zealand libraries with a mean of US\$1,600,224. European libraries had an expenditure mean of US $\$ 500,055$, Central and South American libraries had a mean of US\$384,097 and Asian libraries had a mean of US\$339,244. African libraries had a mean of US $\$ 134,725$ and Middle Eastern libraries had the lowest mean at US $\$ 49,890$.

If one compares university law school libraries in two regions where we have large statistical samples: in North America the mean annual spend was US\$1,736,052 (from a sample of 28 libraries) whilst in Europe the mean annual spend was much lower at US\$356,076 (from a sample of 28 libraries).

\section{Spend per patron on law materials}

Another way of analysing law library expenditure, is to calculate the average spend per patron on law materials. Overall across all types of library and all regions the spend per patron on law materials ranged from US\$1.34 to US\$21,336. The overall average spend per patron was US\$1,094 and the median was US\$505.

By type of library, the highest mean spend per patron was in Court Libraries with a mean of US $\$ 4,962$. This was followed by law firm libraries with a mean of US $\$ 1,760$ and research institute libraries with a mean of US\$1,698. The remaining means were much lower with university law school libraries at US\$775, government department libraries at US\$434 and Bar / Law society libraries at US\$119.

By region, the highest mean spend per patron by far was in Australia and New Zealand libraries with a mean of US $\$ 4,844$. This was followed by North American libraries with a mean of US\$1,528. The remaining regions were much lower with European libraries at US\$626, Central and South American libraries at US\$507, African libraries at US\$379, Asian libraries at US\$295 and finally Middle Eastern libraries at US\$110.

It is interesting to note that the highest to lowest rankings for types of library were different when using the different statistical methods. In fact by type of library there were three changes of ranking between (i) the highest to lowest order for average expenditure on law materials and (ii) the highest to lowest order for spend per patron on law materials.

\subsection{Expenditure on print materials}

Slightly fewer libraries were able to provide annual expenditure figures for print only law materials (i.e. 91 libraries or $73 \%$ of respondents rather than the 96 libraries who gave total expenditure figures on law materials). Total annual expenditure on the acquisition of print only law materials in major law libraries around the world ranged from US $\$ 2,808$ to US $\$ 3,396,370$. The overall mean expenditure was US $\$ 610,459$ and the median was US\$312,762.

By type of library, the highest to lowest order for print only law materials was very similar to the order for the figures for total expenditure on law materials. The highest average expenditure on print only law materials was again in Court libraries with a mean of US $\$ 1,165,961$. Again this was followed by research institute libraries with a mean of US $\$ 717,537$ and university law school libraries with a mean of US\$669,040. Bar / Law society libraries had a mean of US\$217,095, law firm libraries had a mean of US\$179,235 and government department libraries had a mean of US\$154,142. 
By region, the highest to lowest order for print only law materials was again very similar to the order for the figures for total expenditure on law materials. The two highest average expenditures on print only law materials were again in North American libraries with a mean of US\$1,268,811 and in Australian and New Zealand libraries with a mean of US\$1,156,396. Central and South American libraries had a mean of US\$307,396, European libraries had a mean of US\$303,652 and Asian libraries had a mean of US $\$ 199,368$. African libraries had a mean of US\$70,525 and Middle Eastern libraries had the lowest mean at US\$31,811.

\section{Proportion spent on print only materials}

Comparing the figures for average total expenditure on law materials against the figures for average expenditure on print only law materials, the average percentage spend on print only law materials by type of library was 74\% for Court libraries, $71 \%$ for research institute libraries, $70 \%$ for Bar / Law society libraries, $66 \%$ for university law school libraries, $49 \%$ for government department libraries and 39\% for law firm libraries.

Similarly the average percentage spend on print only law materials by region was $72 \%$ in North America, 64\% in Central and South America, 63\% in Australia and New Zealand and Asia, 62\% in the Middle East, and 59\% in both Africa and Europe.

\subsection{Expenditure on electronic materials}

One less library was able to provide annual expenditure figures for electronic only materials (i.e. 90 libraries rather than the 91 libraries that provided expenditure figures for print only law materials and the 96 libraries who gave total expenditure figures on law materials). Total annual expenditure on the acquisition of electronic only law materials in major law libraries around the world ranged from US\$356 to US $\$ 2,032,950$. The overall mean expenditure was US $\$ 275,774$ and the median was US\$205,007.

By type of library, the highest to lowest order for electronic only law materials was not similar to the order for the figures for total expenditure on law materials. The highest average expenditure on electronic only law materials was in law firm libraries with a mean of US $\$ 480,122$. This was followed by Court libraries with a mean of US $\$ 357,980$, research institute libraries with a mean of US\$284,260, university law school libraries with a mean of US $\$ 269,620$, government department libraries with a mean of US $\$ 189,047$ and Bar / Law society libraries with a mean of US\$53,428.

By region, the highest to lowest order for print only law materials was similar to the order for the figures for total expenditure on law materials. The two highest average expenditures on electronic only law materials were again in North American libraries with a mean of US\$457,841 and in Australian and New Zealand libraries with a mean of US $\$ 439,382$. European libraries had a mean of US $\$ 211,794$, Asian libraries had a mean of US\$137,771 and Central and South American libraries had a mean of US $\$ 115,052$. Middle Eastern libraries had a mean of US\$69,460 and African libraries had the lowest mean at US\$64,201.

\section{Proportion spent on electronic only materials}

Comparing the figures for total expenditure on law materials against the figures for expenditure on electronic only law materials, the average percentage spend on electronic only law materials by type of library was $61 \%$ for law firm libraries, $51 \%$ for government department libraries, 34\% for university law school libraries, 30\% for Bar / Law society libraries, $29 \%$ for research institute libraries and $26 \%$ for Court libraries. 
Similarly the average percentage spend on electronic only law materials by region was $41 \%$ in both Africa and Europe, 38\% in the Middle East, 37\% in both Australia and New Zealand and Asia, 36\% in Central and South America, and 28\% in North America.

\section{Conclusions}

In most Court libraries, research institute libraries, Bar / Law society libraries and university law school libraries, the majority of annual acquisitions budgets were spent on print materials. Alternatively in most government department libraries and law firm libraries, the majority of annual acquisitions budgets were spent on electronic materials. In all regions, libraries spent the majority of their annual acquisitions budget on print materials.

\section{Staffing}

The responses to the questions on staffing provide a picture of the number and qualifications of library staff in major law libraries around the world. Libraries were asked how many library staff (on all grades) spent $50 \%$ or more of their working time on the care and servicing of the print and electronic law collections. Responses were requested in terms of full time equivalents (FTE's).

\subsection{Number of law library staff}

117 libraries or $94 \%$ of respondents reported on the number of staff who spent $50 \%$ or more of their time working in the law library. The overall range in terms of FTE's was from 0.5 staff to 244 staff. The overall mean number of staff was 13.17 and the median was 6.

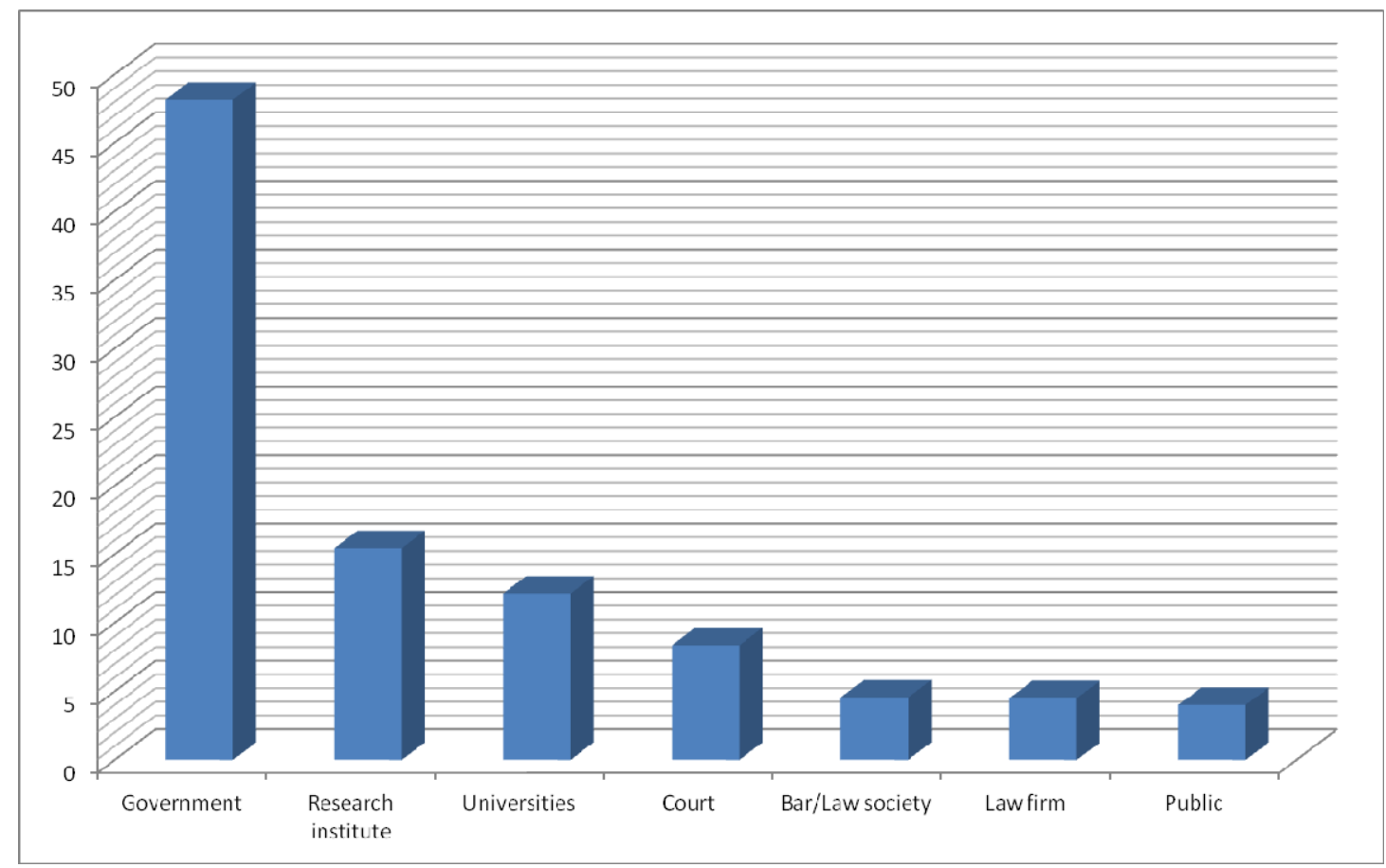

Graph 9: Average number of library staff in major law libraries around the world

As the above graph shows, by type of library the highest average number of staff by far was found in government department libraries with a mean FTE of 48.14 staff. This was followed by research institute libraries with a mean FTE of 15.43 staff, university law school libraries with a mean FTE of 12.12 staff and Court libraries with a mean FTE of 8.35 staff. Bar / Law society libraries had a mean FTE of 4.55 staff, 
law firms had a mean FTE of 4.50 staff and public libraries had a mean FTE of 4.00 staff.

By region, Central and South American libraries had the highest average number of staff by far with a mean FTE of 89.00 staff (although please note that the sample was only 3 libraries). This was followed by North American libraries with a mean FTE of 19.6 staff. Asian libraries had a mean FTE of 9.89 staff, European libraries had a mean FTE of 8.65 staff, Australian and New Zealand libraries had a mean FTE of 6.15 staff and African libraries had a mean FTE of 6.0 staff. Middle Eastern libraries had the lowest mean FTE of 3.50 staff.

\subsection{Professional librarian posts}

Respondents were asked how many of their total number of staff FTE's were professional librarian posts. Slightly fewer libraries responded to this question than had done to the previous question (i.e. 115 libraries rather than 117 libraries). The overall range in terms of FTE's was from 0.5 professional staff to 36 professional staff. The overall mean number of professional library staff was 5.45 and the median was 2.

By type of library, we found almost the same highest to lowest order as we found with library staff generally. The highest average number of professional library staff was found in government department libraries with a mean FTE of 10.57 professional staff. This was followed by research institute libraries with a mean FTE of 7.72 professional staff, university law school libraries with a mean FTE of 5.24 professional staff and Court libraries with a mean FTE of 3.85 professional staff. Law firm libraries had a mean FTE of 3.56, public libraries had a mean FTE of 3.50 and Bar / Law society libraries had a mean of 3.42 professional staff.

By region, again we found almost the same highest to lowest order as we found with library staff generally. Central and South American libraries had the highest average number of professional staff by far with a mean FTE of 13.33 (although again please note that the sample was only 3 libraries). This was followed by North American libraries with a mean FTE of 8.28 professional staff. European libraries had a mean FTE of 4.49 professional staff, Asian libraries had a mean FTE of 4.13 professional staff, Australian and New Zealand libraries had a mean FTE of 3.90 professional staff and African libraries had a mean FTE of 2.73 professional staff. Middle Eastern libraries again had the lowest mean FTE of 2.25 professional staff.

\subsection{Proportion of library staff in professional roles}

Looking across all library staff, one can also calculate the percentage of staff that were in "professional" roles. The overall mean percentage was $55 \%$ and the median was $50 \%$.

By type of library, law firm libraries had the highest average percentage of library staff in professional roles with a mean of $85 \%$. This was followed by public libraries with a mean of $75 \%$, Bar / Law society libraries with a mean of $71 \%$, government department libraries with a mean of $54 \%$, Court libraries with a mean of $53 \%$ and research institute libraries with a mean of $50 \%$. University law school libraries had the lowest average percentage of library staff in professional roles with a mean of $49 \%$.

By region, Middle Eastern libraries had the highest average percentage of professional library staff with a mean of $68 \%$. This was followed by European libraries with a mean of $64 \%$, Australian and New Zealand libraries with a mean of $61 \%$, African libraries with a mean of $56 \%$, Asian libraries with a mean of $52 \%$ and Central and South American libraries with a mean of 39\%. North American libraries 
had the lowest average percentage of library staff in professional roles with a mean of $38 \%$.

\subsection{Librarianship and information science (LIS) qualification}

Respondents were asked to indicate how many of the staff whose principal function was the care of the law collections had a professional librarianship and information science (LIS) qualification. Responses were requested in terms of full time equivalents (FTE's). 114 libraries or 91\% of respondents reported on how many staff had a professional library qualification. The overall range in terms of FTE's was from 0.5 staff to 55 staff. The overall mean was 5.39 staff and the median was 2 .

By type of library, government department libraries had the highest average number of staff with a professional library qualification with a mean FTE of 10.14 staff. This was followed by research institute libraries with a mean FTE of 8.12 staff, university law school libraries with a mean FTE of 5.48 staff, Court libraries with a mean FTE of 3.70 staff, law firm libraries with a mean FTE of 3.56 staff and Bar / Law society libraries with a mean FTE of 3.33 staff. Public libraries had the lowest average number of staff with a professional library qualification with a mean FTE of 2.00 staff.

By region, Central and South American libraries had the highest average number of staff with a professional library qualification with a mean FTE of 13.33 staff. This was followed by North American libraries with a mean FTE of 8.93 staff. Australian and New Zealand libraries had a mean FTE of 4.35 staff, European libraries had a mean of 3.82 staff, Asian libraries had a mean FTE of 3.5 staff, Middle Eastern libraries had a mean FTE of 3.00 staff. African libraries had the lowest average number of staff with a professional library qualification with a mean FTE of 2.64 staff.

\subsection{Proportion of staff with a professional library qualification}

Looking across all library staff, one can also calculate the percentage of staff that had a professional library qualification. The overall mean percentage was $54 \%$ and the median was $50 \%$.

By type of library, law firm libraries had the highest average percentage of library staff with a library qualification with a mean of $85 \%$. This was followed by Bar / Law society libraries with a mean of $70 \%$, government department libraries with a mean of $59 \%$, research institute libraries with a mean of $53 \%$ and university law school libraries with a mean of $50 \%$. Court libraries had the lowest average percentage of library staff with a library qualification with a mean of $49 \%$.

By region, Australian and New Zealand libraries had the highest average percentage of library staff with a library qualification with a mean of $73 \%$. This was followed by Middle Eastern libraries with a mean of $68 \%$, European libraries with a mean of $62 \%$, African libraries with a mean of $54 \%$, Asian libraries with a mean of $42 \%$ and North American libraries with a mean of $40 \%$. Central and South American libraries had the lowest average percentage of library staff with a library qualification with a mean of $39 \%$.

\section{Library contribution to training professional law librarians}

A full list of the training and staff development opportunities offered by libraries for their professional law librarians is contained in Appendix 7. A summary of responses by type of library is provided below.

\section{University law school libraries}

Almost all university law school libraries offered their law librarians opportunities to attend both in-house training and external training courses to improve their 
professional development. In-house training ranged from vendor training on databases to internal mentoring programmes to on-the-job training. External training courses ranged from financing attendance at specific courses to attending conferences held by national associations of law libraries such as IALL, AALL, BIALL and CALL. Several libraries linked in to training offered by their university's library and information studies departments and some libraries offered short-term practical training placements to library and information studies students. Interestingly webinars were becoming an increasingly popular medium to provide staff training.

\section{Research institute libraries}

In-house training and external staff development opportunities were provided. Impressively the larger research institute libraries hosted training opportunities and placements for law librarians from other libraries, sometimes outside their jurisdiction.

\section{Court libraries}

In-house database training by vendors, on-the-job training, visits to other libraries and financing attendance to external regional conferences were all provided. One Court library offered training sessions for library and information studies students studying at regional universities and practical work placements.

\section{Government department libraries}

Again both in-house training and external courses were provided. One library regularly sent librarians on placement to other jurisdictions.

\section{Law firm libraries and Bar I Law society libraries}

Much more emphasis on in-house training courses and on-the-job training, although librarians were sent on external specialised courses as necessary.

\section{Legal research skills training}

Legal research skills training is defined for the survey in terms of instruction, for example, in how to understand legal abbreviations and in the use of particular law publications or databases. It is not concerned with basic introductions to the library or the library catalogue or induction tours.

\subsection{Total number of libraries offering legal research skills training}

123 libraries or $99 \%$ of respondents completed this part of the questionnaire and $87 \%$ of these (i.e. 107 major law libraries) confirmed that they provided some form of legal research skills training.

By type of library, all public library respondents provided legal skills training. This was followed by $95 \%$ of university law school libraries, $89 \%$ of law firm libraries, $83 \%$ of research institute libraries, $62.5 \%$ of government department libraries and $50 \%$ each of Court libraries and Bar / Law society libraries.

By region, all respondent libraries in North America provided legal research skills training. This was followed by $92 \%$ of libraries in Europe, $89 \%$ of libraries in Asia, $75 \%$ of libraries in the Middle East, $70 \%$ of libraries in Australia and New Zealand, $67 \%$ of libraries in Central and South America and $54 \%$ of libraries in Africa.

By analysing the figures by both type of library and region, it is very interesting to compare university law school libraries in different regions. Impressively all university law school library respondents in North America, Europe, Central and South America, Australia and New Zealand, and Asia provided legal research skills training. $75 \%$ of university law school libraries in the Middle East provided this training and 
$62.5 \%$ of university law school libraries in Africa provided legal research skills training.

\section{Conclusions}

Legal research skills training provided by libraries was a key service for the majority of libraries within each type of library. It was also a key service for the majority of libraries within each region.

\subsection{Who provided the legal research skills training?}

Overall in 101 libraries (that is in 90\% of responding institutions) library staff were involved in providing legal research skills training. External trainers were involved with legal research training in $46 \%$ of responding libraries, law school lecturing staff were involved in $40 \%$ of libraries, Lexis Student Associates were involved with $12.5 \%$ of libraries and other staff were involved in just $2 \%$ of libraries.

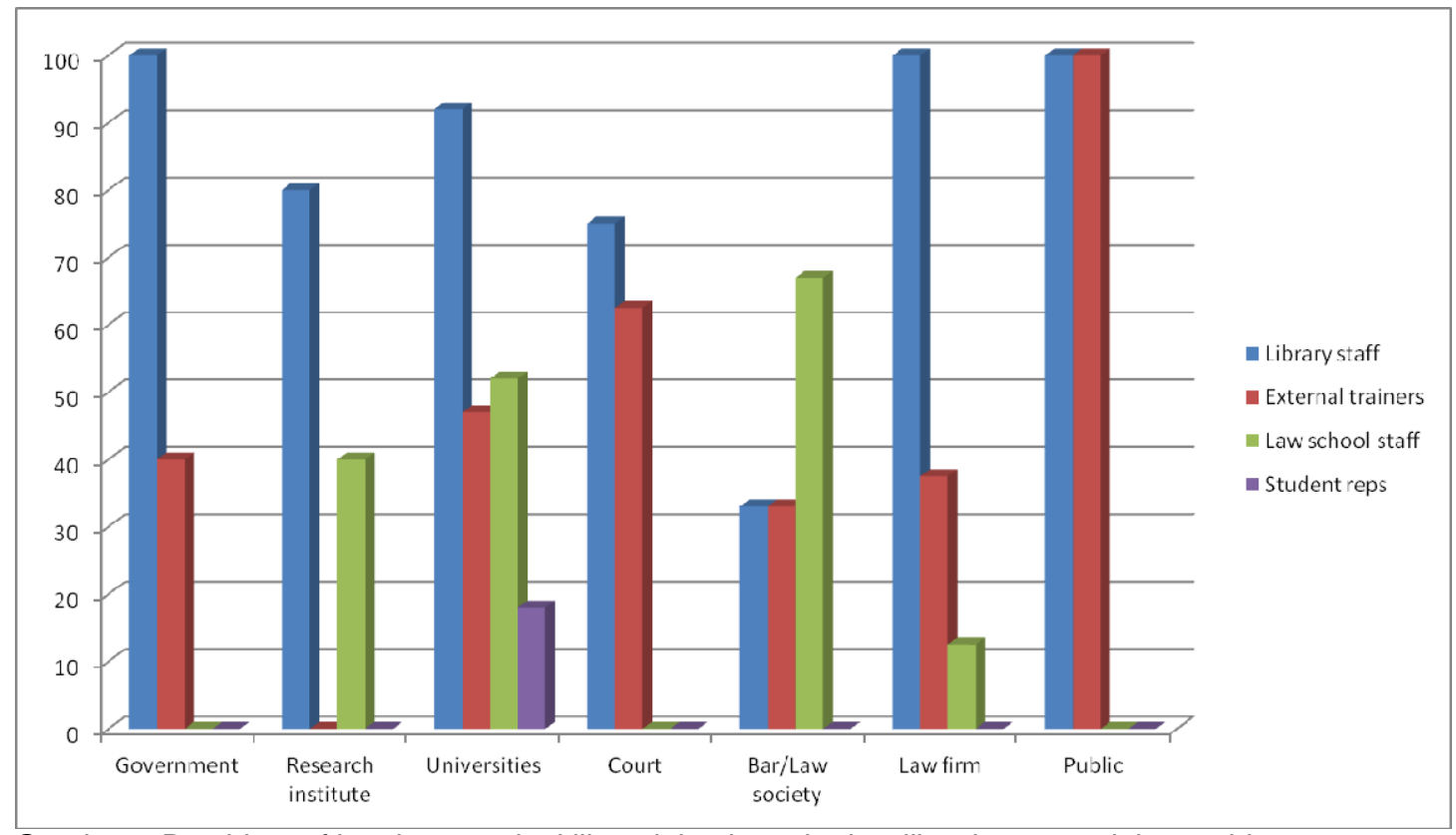

Graph 10: Providers of legal research skills training in major law libraries around the world

As the graph above shows, by type of library, library staff were involved in providing legal research skills in all governmental department libraries, law firm libraries, Bar I Law society libraries and public libraries. This library staff involvement percentage fell slightly to $92 \%$ in university law school libraries, $80 \%$ in research institute libraries, $75 \%$ in Court libraries and 33\% in Bar / Law society libraries.

By type of library, external trainers were involved in providing legal research skills in all public libraries, $62.5 \%$ of Court libraries, $47 \%$ of university law school libraries, $40 \%$ of government department libraries, $37.5 \%$ of law firm libraries and $33 \%$ of Bar I Law society libraries. External trainers were not involved at all in providing legal research skills in research institute libraries.

By type of library, law school lecturing staff were involved in providing legal research skills in $67 \%$ of Bar / Law society libraries, $52 \%$ of university law school libraries, $40 \%$ of research institute libraries and only $12.5 \%$ of law firm libraries. As could be expected, law school lecturing staff were not involved at all in providing legal research skills training in Court libraries, government department libraries and public libraries. 
By type of library, Lexis Student Associates were involved in providing research skills in $18 \%$ of university law school libraries. They were not involved in providing this training in any other type of library.

\section{Conclusions}

These figures suggest that library staff were the most significant trainers in legal research skills in major law libraries around the world, with external trainers and law school lecturing staff generally far less involved and Lexis Student Associates and other staff even less involved. The overall picture is a mix of contributors to legal research skills training in libraries, but with law librarians retaining the key role in the overwhelming majority.

\subsection{Which patrons received research skills training by library staff?}

108 libraries or $87 \%$ of respondents indicated for which law courses legal research skills training was provided by library staff. Overall in $66 \%$ of major law libraries, library staff provided legal research skills training to taught-course law postgraduates (e.g. LLM students). In 55\% of libraries library staff trained research degree in law students (e.g. MPhil or PhD students), in $52 \%$ of libraries library staff trained law undergraduates, in $46 \%$ of libraries library staff trained Juris Doctor students, in $24 \%$ of libraries library staff trained lawyers, in $19 \%$ of libraries library staff trained trainee lawyers, in $18 \%$ of libraries library staff trained professional practice qualification students (e.g. students studying for the Bar exams), in 15\% of libraries library staff trained court officials, in $13 \%$ of libraries library staff trained the non fee-paying public, in $11 \%$ of libraries library staff trained judges and in only $3 \%$ of libraries did library staff train the fee-paying public.

\section{Legal research skills training by library staff in university law school libraries} In $82 \%$ of university law school libraries, library staff provided legal research skills training to taught-course law postgraduates. In $64 \%$ of these libraries, library staff provided legal research skills training to research degree students, in $61 \%$ of these libraries library staff provided training to undergraduate students, in $55 \%$ of these libraries library staff provided training to JD students, in $14 \%$ of these libraries library staff provide training to professional practice qualification students, in $9 \%$ of these libraries library staff provided training to the non fee-paying public, in $8 \%$ of these libraries library staff provided training to lawyers, in $4 \%$ of these libraries library staff provided training to trainee lawyers and court officials and in $3 \%$ of these libraries library staff provided training to judges and the fee-paying public.

\section{Some conclusions}

In both libraries overall and in university law school libraries, library staff were most likely to provide research skills training to taught-course postgraduates, then research degree students, then undergraduates and then JD students. In both libraries overall and university law school libraries, library staff were least likely to provide this training to the fee-paying public.

\section{Legal research skills training by library staff in university law school libraries in North America}

In $97 \%$ of university law school libraries in North America, library staff provided legal research skills training to JD students. In $83 \%$ of these libraries, library staff provided legal research training to taught-course postgraduates, in $59 \%$ of these libraries library staff provided training to research students, in $14 \%$ of these libraries library staff provided training to undergraduate students, in $10 \%$ of these libraries library staff provided training to lawyers, in $7 \%$ of these libraries library staff provided training to the non fee-paying public and in $3 \%$ of these libraries library staff provided training to professional practice qualification students and court officials. Library staff 
in this type of library in this region did not provide legal research skills training to the fee-paying public, judges and trainee lawyers.

\section{Legal research skills training by library staff in university law school libraries in Europe \\ In $96 \%$ of university law school libraries in Europe, library staff provided legal research skills training to taught-course postgraduates. In $92 \%$ of these libraries, library staff provided legal research training to undergraduate students, in $81 \%$ of these libraries library staff provided training to research students, in $27 \%$ of these libraries library staff provided training to professional practice qualification students, in $23 \%$ of these libraries library staff provided training to JD students, in $4 \%$ of these libraries library staff provided training to judges, court officials, trainee lawyers and the non fee-paying public. Library staff in this type of library in this region did not provide legal research skills training to the fee-paying public and lawyers.}

\section{Some conclusions}

In North American university law school libraries, Library staff were most likely to provide research skills training to JD students, whilst in European university law school libraries, library staff were most likely to provide research skills training to taught-course postgraduates. In both North American and European university law school libraries, library staff did not provide research skills training to the fee-paying public.

\subsection{Delivering legal research skills training}

89 libraries or $72 \%$ of respondents reported on the number of library staff hours spent in delivering legal research skills training during the year. Preparation time was excluded. The overall range was from 3.5 hours a year to 1,500 hours a year. The overall mean was 133 hours and the median was 70 hours.

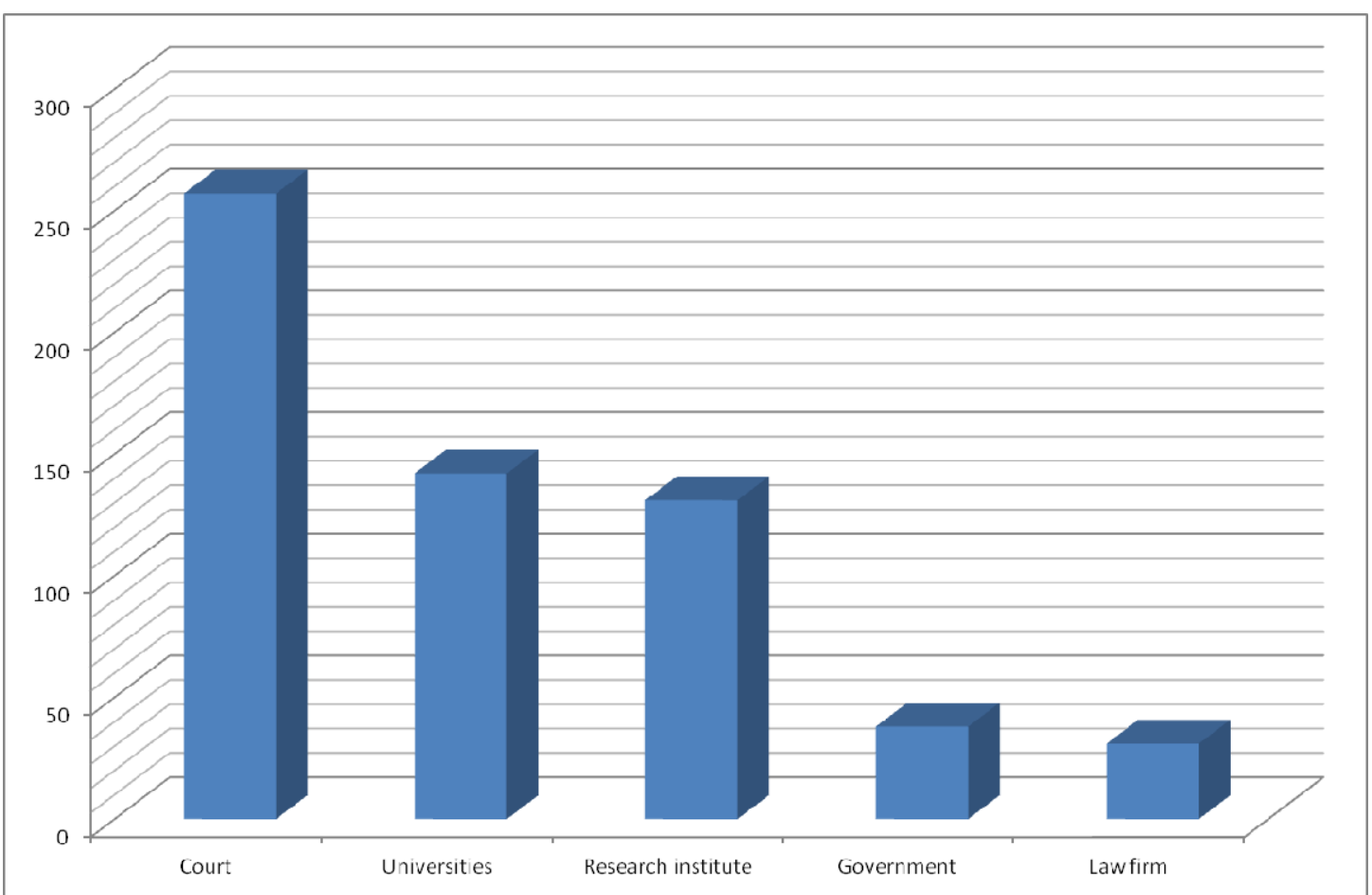

Graph 11: Average number of contact training hours with patrons in major law libraries around the world

As the graph above shows, by type of library Court libraries had the highest average number of training contact hours with 257 hours a year. This was followed by university law school libraries with a mean of 142 hours and research institute 
libraries with 131 hours. Government department libraries and law firm libraries had the lowest mean number of training contact hours with 38 hours and 31 hours

respectively. Bar / Law society libraries provided no figures for training contact hours.

By region, Asian libraries and North American libraries had the two highest average number of training contact hours with 330 hours a year and 216 hours a year respectively. These were followed by African and Middle Eastern libraries each with a mean of 87 hours and Australian and New Zealand libraries with a mean of 83 hours. European libraries had the lowest mean number of training contact hours with 73 hours a year.

\subsection{Methods of delivery}

104 libraries or $84 \%$ of respondents indicated which methods of delivery were used by library staff to facilitate the training on legal research skills.

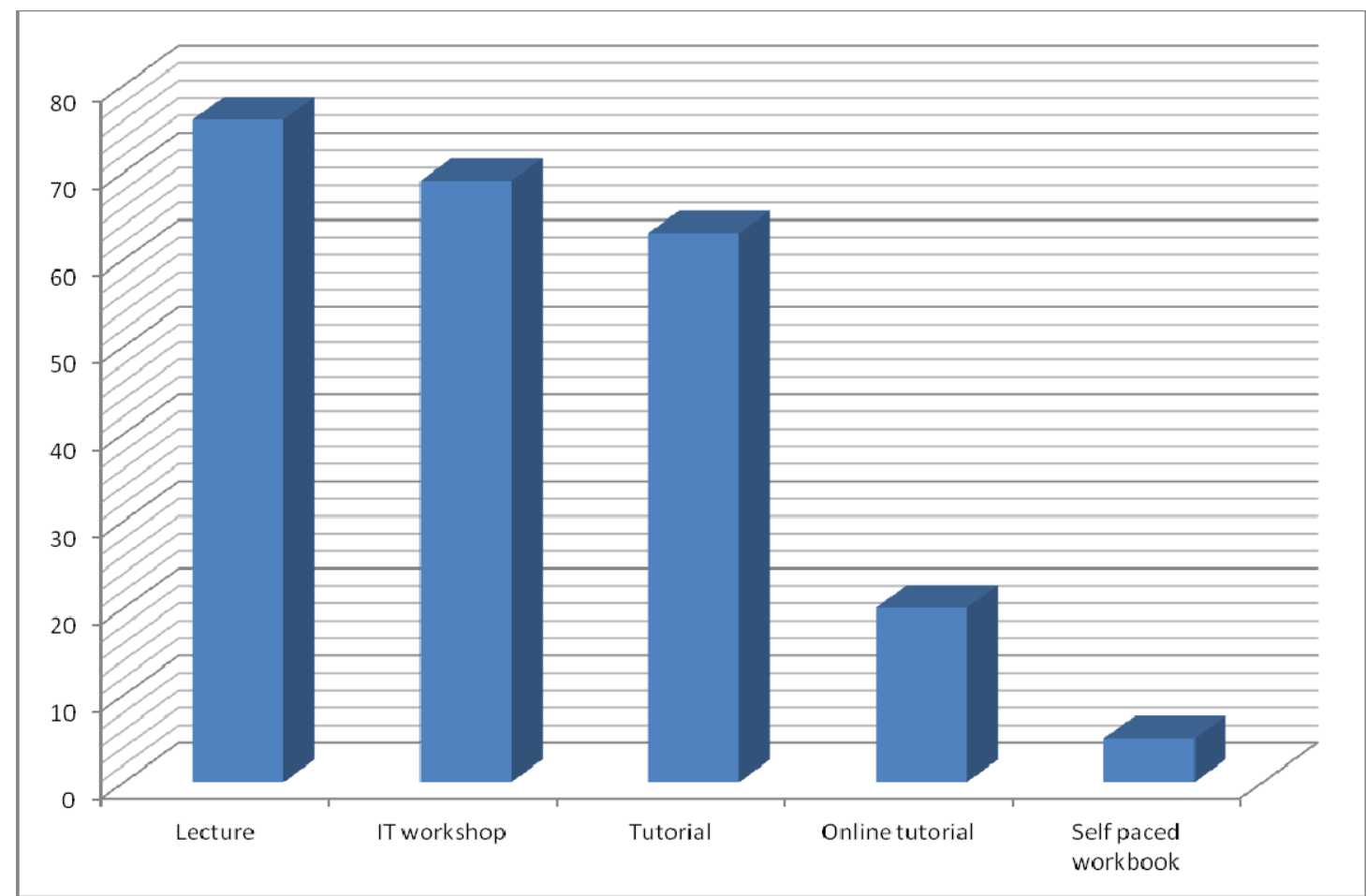

Graph 12: Most popular training delivery method in major law libraries around the world

As the graph above shows, overall the most popular method of delivering training was by lecture which was used by $76 \%$ of major law libraries. The next most popular method was by IT workshop in an IT room which was used by $69 \%$ of libraries. Tutorial in a seminar room was the next most popular method at $63 \%$. The remaining delivery methods were much less popular with online tutorial at $20 \%$ and student's self-paced workbook and video both at $5 \%$.

The lecture was also the most popular training delivery method in university law school libraries, research institute libraries (though tying with the tutorial method), government department libraries (though tying with the IT workshop method), Bar I Law society libraries and public libraries (though tying with the IT workshop method). In Court libraries the most popular training delivery method was by tutorial with the IT workshop the next most popular and then the lecture. In law firm libraries the IT workshop was the most popular with the tutorial and the lecture both tying as the next most popular. 
The lecture was also the most popular training method in most regions. However the tutorial was the most popular in Australia and New Zealand and the IT workshop was the most popular in Asia and the Middle East.

\section{Conclusions}

It is clear that the three most popular training delivery methods in libraries around the world were the lecture, the IT workshop and the tutorial. The order of popularity of these three methods changed slightly with type of library and region, but the lecture method still predominated.

\section{Web-based services for patrons}

In order to identify and compare the web based services offered to patrons in different types of library and in different regions, respondents were asked about their management, contribution or lack of any involvement with the Library Management System, the VLE, the institutional repository and the design and content of law library webpages. A full list of library comments on their web-based services is listed by type of library in Appendix 8.

\subsection{Library staff and the Library Management System (LMS)}

109 libraries or $88 \%$ of respondents reported on whether library staff managed or contributed to operating the Library Management System (LMS). Overall in the majority of these libraries (i.e. 51\%), library staff managed the LMS. In $46 \%$ of libraries library staff contributed to operating the LMS, and in only $3 \%$ of libraries were library staff not involved in any way with the LMS.

\section{By type of library}

The LMS was managed by library staff in all Bar / Law society libraries. The LMS was also managed by library staff in $89 \%$ of Court libraries, in $75 \%$ of research institute libraries, government department libraries and law firm libraries and in only 38\% of university law school libraries. Library staff contributed to operating the LMS in $58 \%$ of university law school libraries, in $25 \%$ of research institute libraries, government department libraries and law firm libraries and in $11 \%$ of Court libraries. In all these types of libraries therefore library staff had a role in some way with the LMS.

However in $4 \%$ of university law school libraries, library staff were not involved in any way with the LMS.

\subsection{Library staff and the Virtual Learning Environment (VLE)}

106 libraries or $86 \%$ of respondents reported on whether library staff managed or contributed to operating the Virtual Learning Environment (VLE). Overall in only 9\% of these libraries did library staff manage the VLE. In 37\% of these libraries library staff contributed to the VLE, and in $54 \%$ of these libraries (i.e. in the majority) library staff were not involved in any way with administrating the VLE.

\section{By type of library}

The VLE was managed by Library staff in only $25 \%$ of research institute libraries, in $12.5 \%$ of Court libraries and in $9 \%$ of university law school libraries. Library staff contributed to the VLE in $47 \%$ of university law school libraries, $29 \%$ of law firm libraries, $25 \%$ of government department libraries and $12.5 \%$ of Court libraries. In all these types of libraries therefore library staff had a role in some way with the VLE.

However library staff were not involved in any way with the VLE in Bar / Law society libraries. Nor were they involved in $75 \%$ of research institute libraries, Court libraries and government department libraries, in $71 \%$ of law firm libraries and in $44 \%$ of university law school libraries. 


\subsection{Library staff and the institutional repository}

118 libraries or $95 \%$ of respondents reported on whether library staff managed or contributed to the institutional repository. Overall in $28 \%$ of these libraries library staff managed the institutional repository. In $37 \%$ of these libraries library staff contributed to the institutional repository, and in $35 \%$ of these libraries library staff were not involved in any way with the institutional repository.

\section{By type of library}

The institutional repository was managed by library staff in $37.5 \%$ of government department libraries, in $31 \%$ of university law school libraries, in $25 \%$ of Bar / Law society libraries, in $22 \%$ of law firm libraries, in $20 \%$ of research institute libraries and in $10 \%$ of Court libraries. Library staff contributed to the institutional repository in $60 \%$ of Court libraries, in $40 \%$ of research institute libraries, in $39 \%$ of university law school libraries, in $25 \%$ of Bar / Law society libraries, in $22 \%$ of law firm libraries and in $12.5 \%$ of government department libraries. In all these types of libraries therefore library staff had a role in some way with the institutional repository.

However library staff were not involved in any way with the institutional repository in $56 \%$ of law firm libraries, in 50\% of government department libraries and Bar / Law society libraries, in $40 \%$ of research institute libraries and in $30 \%$ of university law school libraries and Court libraries.

\subsection{Library staff and the design of the law library webpages}

116 libraries or $93.5 \%$ of respondents reported on whether library staff managed or contributed to the design of the law library webpages. Overall in a majority of these libraries (i.e. 57\%) library staff managed the design of the law library webpages. In $38 \%$ of libraries library staff contributed to the design of the law library webpages, and in only $5 \%$ of libraries were library staff not involved in any way with the design of the law library webpages.

\section{By type of library}

The design of the law library webpages was managed by library staff in $78 \%$ of law firm libraries. The design was also managed by library staff in $70 \%$ of Court libraries, $67 \%$ of research institute libraries, $62.5 \%$ of government department libraries and $54 \%$ of university law school libraries. Library staff contributed to the design of the law library webpages in all of the Bar / Law society libraries, in $41 \%$ of university law school libraries, in 33\% of research institute libraries, in 30\% of Court libraries, in $22 \%$ of law firm libraries and in $12.5 \%$ of government department libraries. In all these types of libraries therefore library staff had a role in some way with designing the law library webpages.

However in $25 \%$ of government department libraries and in $5 \%$ of university law school libraries library staff were not involved in any way with the design of the law library webpages.

\subsection{Library staff and the content of the law library webpages}

119 libraries or $96 \%$ of respondents reported on whether library staff managed or contributed to the content of the law library webpages. Overall in the majority of these libraries (i.e. in 75\%), library staff managed the content of the law library webpages. In $21 \%$ of libraries library staff contributed to the content of the law library webpages, and in only $4 \%$ of libraries were library staff not involved in any way with the content of the law library webpages. 


\section{By type of library}

The content of law library webpages was managed by library staff in all research institute libraries, in $78 \%$ of university law school libraries and law firm libraries, in $70 \%$ of Court libraries, in $62.5 \%$ of government department libraries and in only $25 \%$ of Bar / Law society libraries. Library staff contributed to the content of the law library webpages in $75 \%$ of Bar / Law society libraries, in $30 \%$ of Court libraries, in $22 \%$ of law firm libraries, in $18 \%$ of university law school libraries and in $12.5 \%$ of government department libraries. In all these types of libraries therefore library staff had a role in some way with the content of the law library webpages.

However in $25 \%$ of government department libraries and in $4 \%$ of university law school libraries library staff were not involved in any way with the content of the law library webpages.

\section{Conclusions}

In terms of these key web-based services for patrons, major law libraries were least likely to be involved in some role with their institutional VLE, whilst they were most likely to be involved in some way with their Library Management System and the content and design of their law library webpages.

\section{Other services offered to patrons}

The next group of survey questions asked respondents to report on whether their library staff wrote and published professional articles, contributed to subject and research guides, and contributed to other information sources such as web portals or gateways for their patrons. In total 119 libraries or $96 \%$ of respondents replied to these questions.

\subsection{Library staff writing professional articles}

Overall in the majority of these libraries (i.e. in 52\%), library staff wrote and published professional articles.

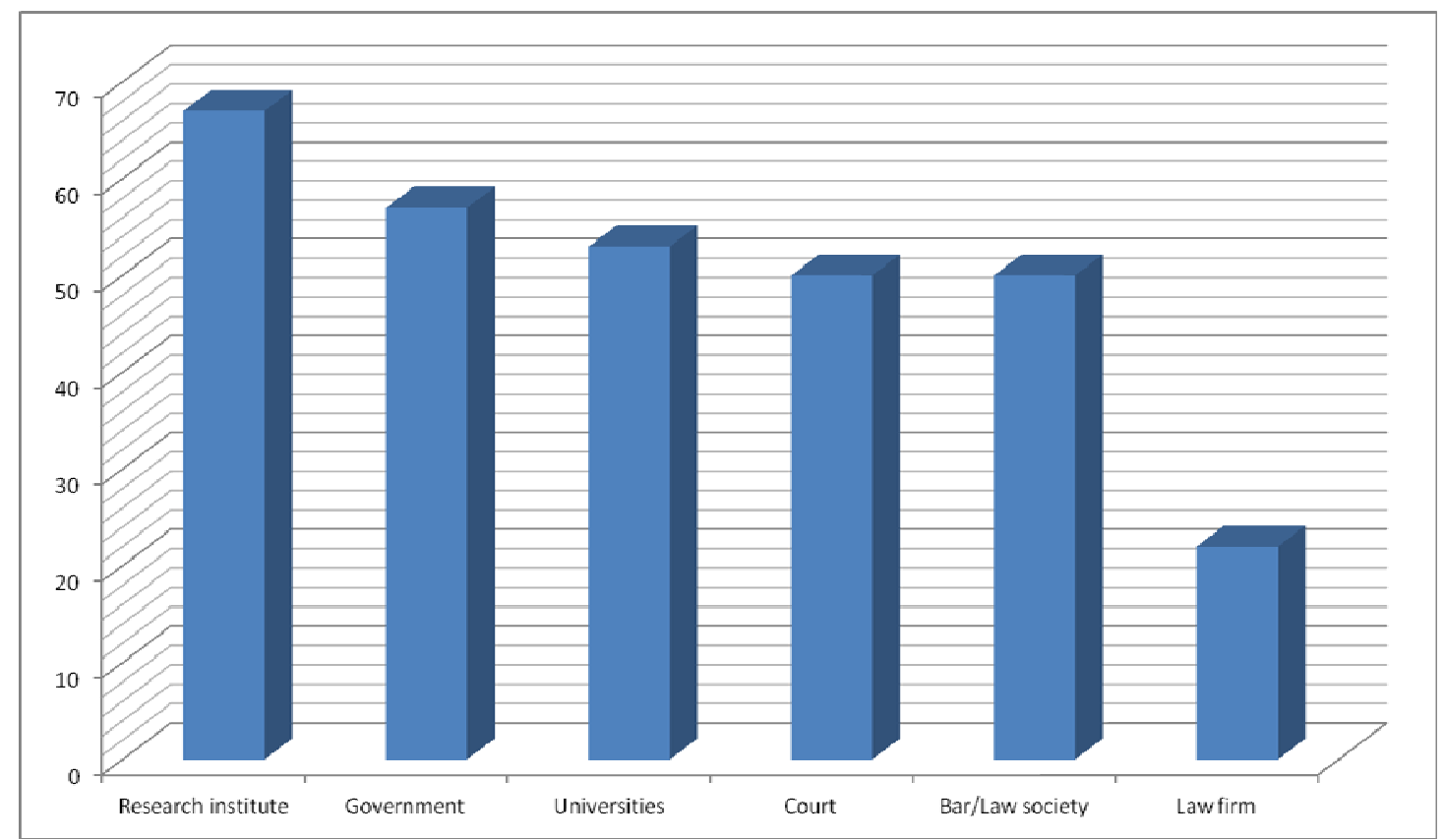

Graph 13: Likelihood of librarians writing and publishing articles in major law libraries around the world

As the graph above shows, by type of library, library staff were most likely to write and publish professional articles in research institute libraries (67\%). In highest to lowest order of likelihood, this was followed by government department libraries 
(57\%), university law school libraries (53\%), Court libraries (50\%) and Bar / Law society libraries (50\%). Library staff in law firm libraries were the least likely to write professional articles (22\%).

By region, library staff were most likely to write and publish professional articles in African libraries (69\%). In highest to lowest order of likelihood, this was followed by North American libraries (68\%), Asian libraries (56\%) and Australian and New Zealand libraries (50\%), Middle Eastern libraries (50\%) and European libraries (39\%). Library staff in Central and South American libraries were the least likely to write professional articles (39\%).

\subsection{Library staff contribution to subject and research guides}

Overall in the overwhelming majority of libraries (i.e. in 91\%), library staff contributed to subject and research guides.

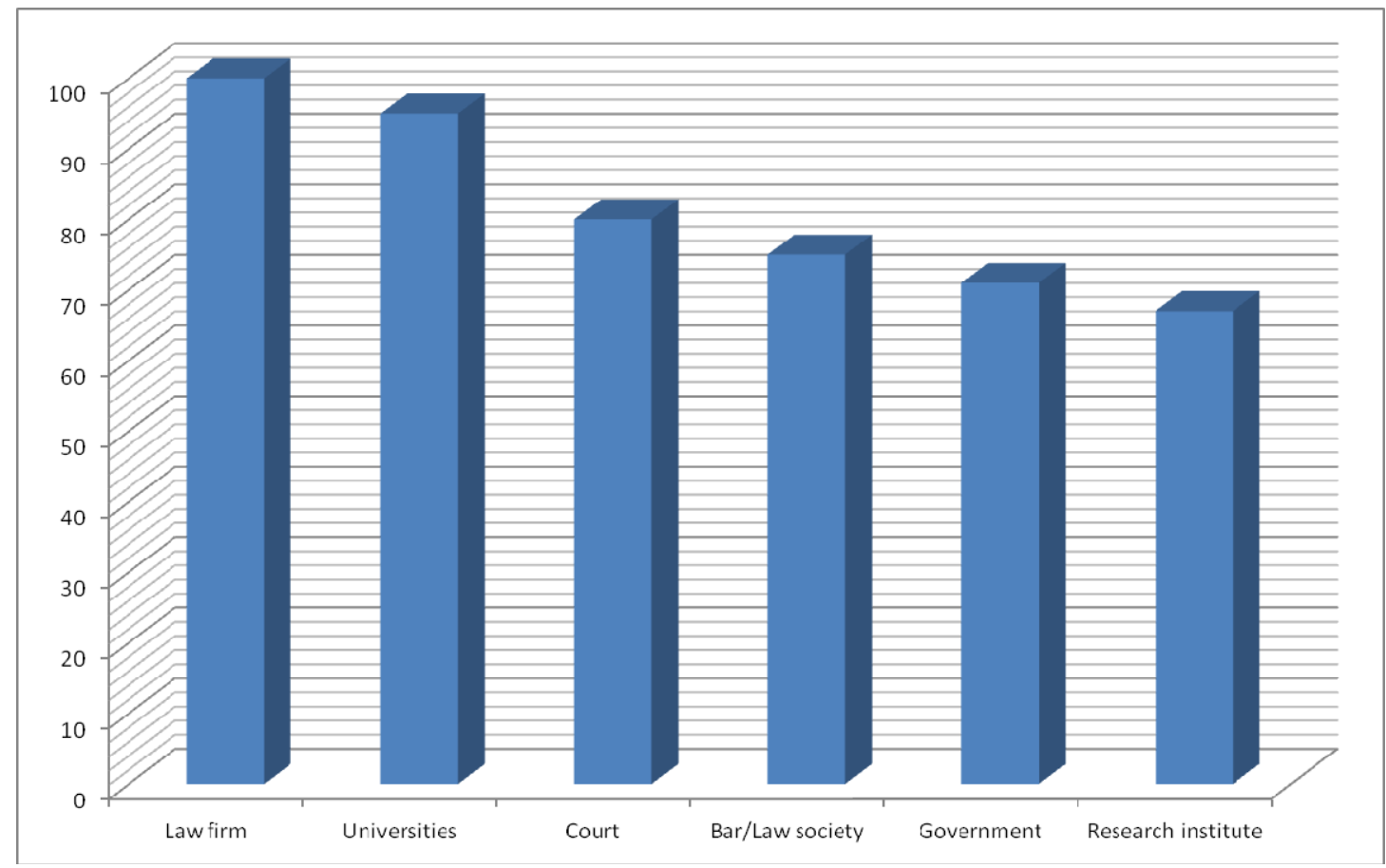

Graph 14: Likelihood of librarians contributing to guides in major law libraries around the world

As the graph above shows, by type of library, library staff were most likely to contribute to subject and research guides in law firms (100\%). In highest to lowest order of likelihood, this was followed by university law school libraries (95\%), Court libraries (80\%), Bar / Law society libraries (75\%) and government department libraries (71\%). Library staff in research institute libraries were the least likely to contribute to subject and research guides (67\%), although this percentage is still very high and shows that in the majority of this type of library the writing of guides was still a key service.

By region, library staff were most likely to contribute to subject and research guides in North American and Middle Eastern libraries (100\% each). In highest to lowest order of likelihood, these were followed by African libraries (92\%), European libraries (90\%), Australian and New Zealand libraries (80\%) and Asian libraries (78\%). Library staff in Central and South American libraries were the least likely to contribute to subject and research guides (67\%), although again this percentage is still very high and shows that for the majority of libraries in this region the creation of guides was still an important service. 


\subsection{Library staff contribution to web portals or gateways}

Overall in the majority of libraries (i.e. in 55\%), library staff contributed to other information sources such as web portals or gateways for their patrons.

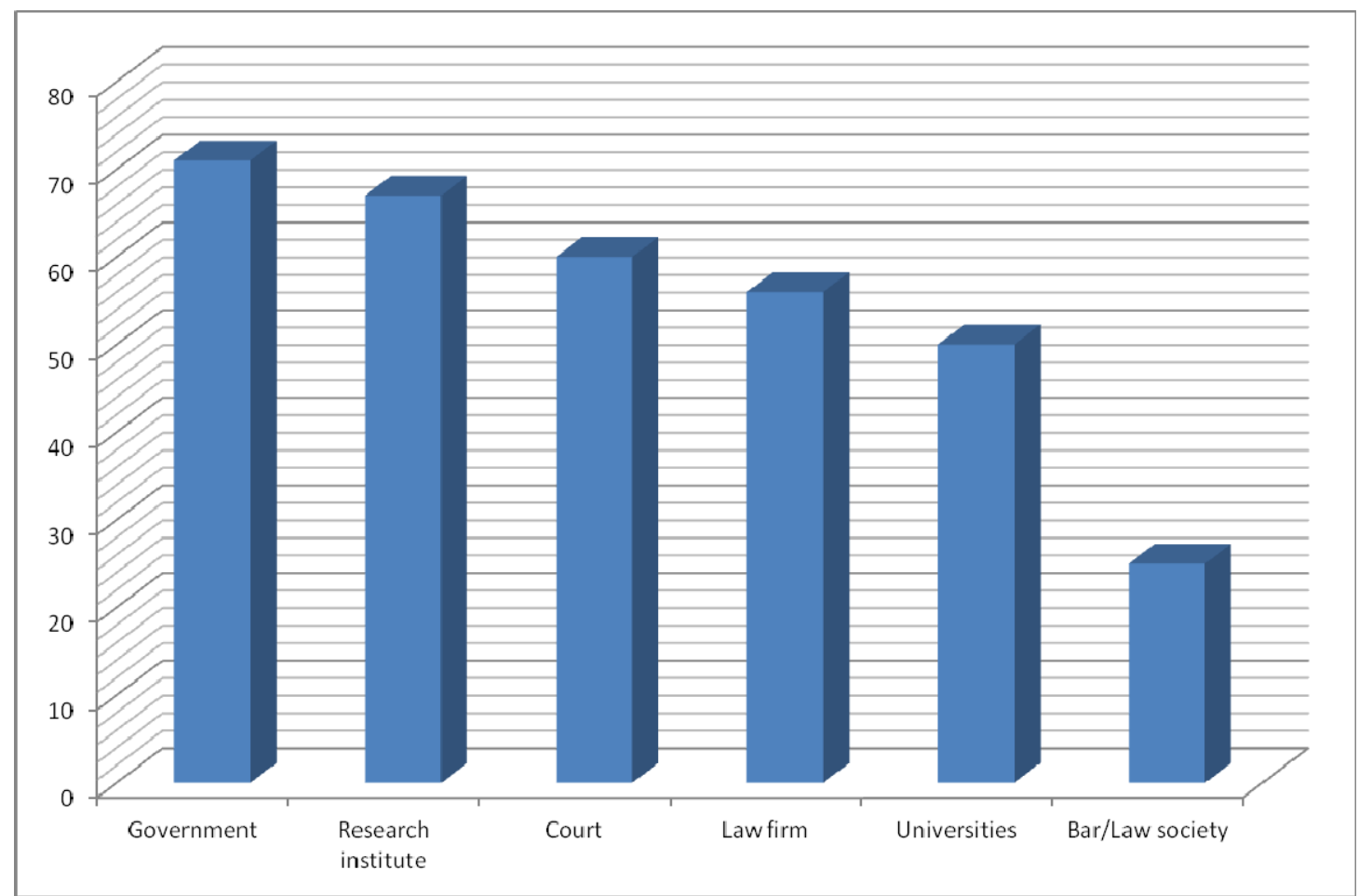

Graph 15: Likelihood of librarians contributing to web portals or gateways in major law libraries around the world

As the graph above shows, by type of library, library staff were most likely to contribute to web portals or gateways in government department libraries (71\%). In highest to lowest order of likelihood this was followed by research institute libraries (67\%), Court libraries (60\%), law firm libraries (56\%) and university law school libraries (50\%). Library staff in Bar / Law society libraries were least likely to contribute to law portals or gateways (25\%).

By region, library staff were most likely to contribute to law portals or gateways in North American libraries (68\%). In highest to lowest order of likelihood, this was followed by Australian and New Zealand libraries (60\%), Asian libraries (56\%), European libraries (51\%), African libraries (46\%) and Central and South American libraries (33\%). Middle Eastern libraries were the least likely to contribute to law portals or gateways (25\%).

\section{Conclusions}

Librarians were contributing to subject and research guides in 91\% of libraries, were contributing to information sources such as web portals or gateways in $55 \%$ of libraries, and were writing professional articles in 52\% of libraries.

\section{Most popular Library Management System}

109 libraries or $88 \%$ of respondents identified the product name of their Library Management System (LMS). Where respondents had mentioned two or more different product names from the same LMS supplier (e.g. Aleph / Aleph Primo or Siris / Siris Dynix or Millennium / Millennium Sierra / Innovative Interfaces Inc) these responses have been added together into a Library Management System total. In 
overall terms, across all types of library and in all regions, the ten most frequently mentioned Library Management Systems are displayed in the following graph:

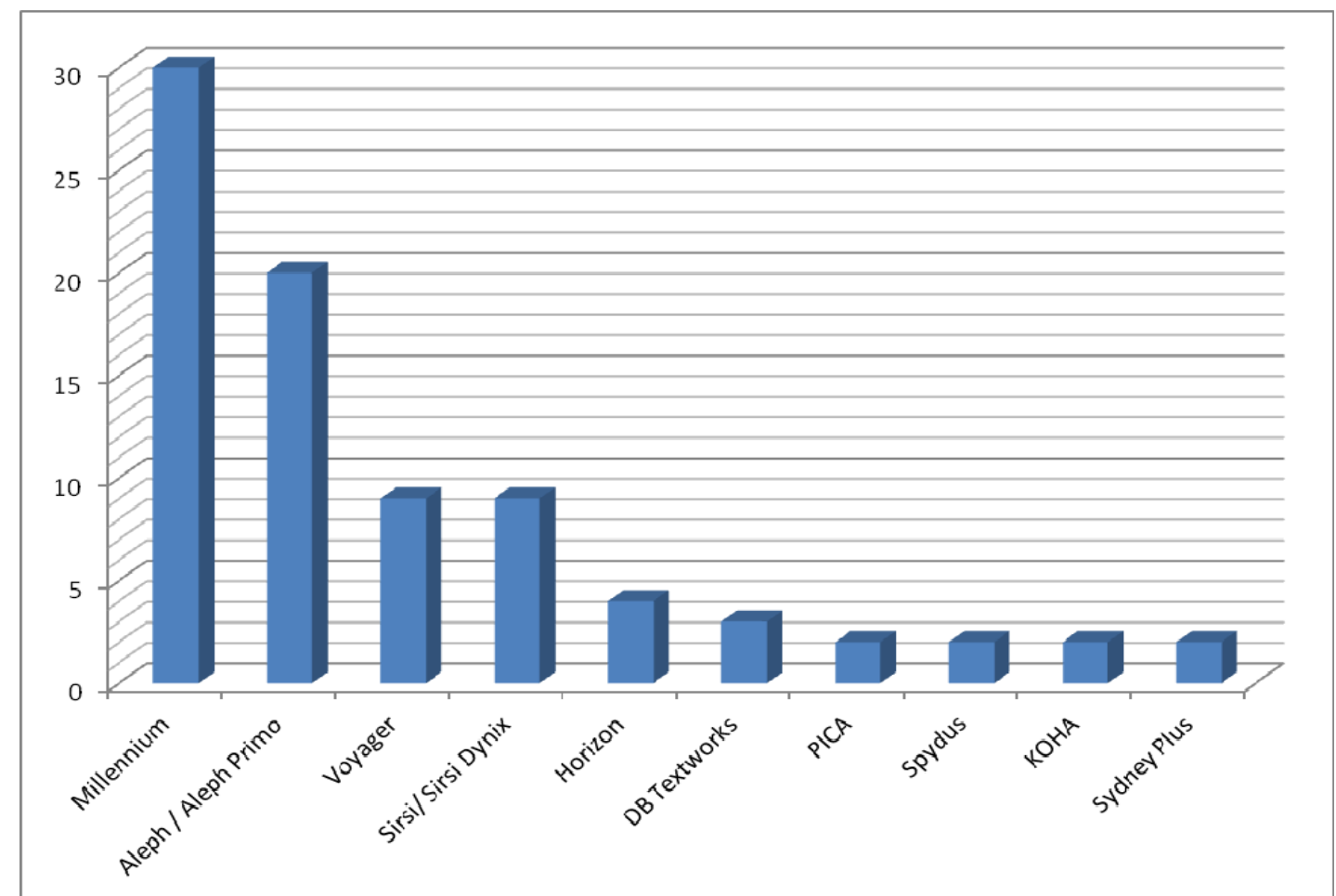

Graph 16: Most popular Library Management System used by major law libraries around the world

As the graph above shows, the two most frequently mentioned Library Management Systems were Millennium supplied by Innovative Interfaces Inc. (mentioned by 30 libraries or $27.5 \%$ of respondents) and Aleph (mentioned by 20 libraries or $18.4 \%$ of respondents). The next group of products had a smaller proportion of the market with both Voyager (ExLibris) and Sirsi mentioned by 9 libraries, Horizon mentioned by 4 libraries and DB Textworks and OCLC PICA mentioned by 3 libraries. Two libraries a piece mentioned Spydus, Koha, and Sydney Plus. The other 22 Library Management Systems were mentioned only once.

\subsection{By type of library:}

\section{University law school libraries}

The same top five Library Management Systems were reported in university law school libraries. Millennium was mentioned by 26 libraries, Aleph was mentioned by 15 libraries, Voyager was mentioned by 8 libraries, Sirsi was mentioned by 7 libraries and Horizon was mentioned by 3 libraries. The other 12 Library Management Systems were mentioned only once.

\section{Research institute libraries}

Aleph and Millennium were both mentioned twice and Vtls Virtua was mentioned once.

\section{Court libraries}

DB Textworks and Sirsi were both mentioned twice. The other 4 Library Management Systems were mentioned only once. These included Millennium. 


\section{Government department libraries}

8 Library Management Systems were mentioned only once. These included Aleph, Horizon and Voyager, but did not include Millennium and Sirsi.

\section{Law firm libraries}

Sirsi was mentioned twice and the other 6 Library Management Systems were mentioned only once. Millennium and Aleph were not mentioned.

\section{Bar I Law society libraries}

Sirsi was mentioned twice and Koha and OLIB were mentioned once.

\section{Public libraries and Other libraries}

5 Library Management Systems were mentioned once. These included Aleph and Millennium.

\section{Conclusion}

By type of library, Millennium, Aleph and Sirsi were the most popular Library Management Systems.

\subsection{By region:}

\section{African libraries}

Millennium, Aleph and Sirsi were all mentioned twice. Koha and Pride were only mentioned once.

\section{North American libraries}

Millennium was mentioned by 14 libraries, Voyager was mentioned by 6 libraries, Aleph was mentioned by 5 libraries and Sirsi was mentioned by 4 libraries. Horizon and Sydney Plus were mentioned once.

\section{Central and South American libraries}

Horizon was mentioned twice and WinISIS was mentioned once.

\section{Australian and New Zealand libraries}

DB Textworks was mentioned twice. The other 7 Library Management Systems were mentioned once. These included Millennium, Sirsi and Horizon, but not Aleph and Voyager.

\section{Middle Eastern libraries}

Millennium was mentioned twice. Alexandrie and Berytos were mentioned once.

\section{European libraries}

Aleph was mentioned by 13 libraries, Millennium was mentioned by 9 libraries, Sirsi was mentioned by 6 libraries and both Voyager and OCLC PICA were mentioned by 3 libraries. The other 13 Library Management Systems were mentioned only once.

\section{Asian libraries}

Millennium was mentioned twice. The other 5 Library Management Systems were mentioned only once. Aleph, Siris, Voyager and Horizon were not mentioned.

\section{Conclusion}

By region, Millennium was the most popular Library Management System, followed by Siris and then Aleph. 


\section{Outreach services for patrons}

The next group of questions asked respondents to report on whether their library staff managed or contributed to outreach services for patrons. In total 108 libraries or $87 \%$ of respondents replied to these questions. A complete list of comments on library outreach services are listed by type of library in Appendix 10.

\subsection{Regular emailing of information to patrons}

Overall in the majority of these libraries (i.e. 52\%), library staff managed the regular emailing of information to patrons and in $43 \%$ of libraries library staff contributed to this regular emailing service. In only $5 \%$ of libraries were library staff not involved in any way with this regular emailing service (or alternatively it could be the case that in some or all of these $5 \%$ of libraries the service was not offered to patrons).

\section{By type of library}

The regular emailing of information to patrons service was managed by library staff in all research institute libraries. The regular emailing service was also managed by library staff in $87.5 \%$ of government libraries, in $78 \%$ of Court libraries, in $62.5 \%$ of law firm libraries and in $43 \%$ of university law school libraries. Library staff contributed to this regular emailing service in all Bar / Law society libraries, in $50 \%$ of university law school libraries, in $25 \%$ of law firm libraries, in $22 \%$ of Court libraries and in $12.5 \%$ of government department libraries. In these types of library therefore library staff had a role in some way with the regular emailing service.

However in $12.5 \%$ of law firm libraries and in $7 \%$ of university law school libraries, library staff were not involved in any way with the regular emailing of information to patrons service (or alternatively it could be the case that in some or all of these libraries the service was not offered to patrons).

\section{By region}

The regular emailing of information to patrons service was managed by library staff in all Central and South American libraries. This regular emailing service was also managed by library staff in $90 \%$ of Australian and New Zealand libraries, in $75 \%$ of Asian libraries, in $67 \%$ of Middle Eastern libraries, in 55\% of African libraries, in $50 \%$ of North American libraries and in $35 \%$ of European libraries. Library staff contributed to this regular emailing service in $58 \%$ of European libraries, in $43 \%$ of North American libraries, in $36 \%$ of African libraries, in $33 \%$ of Middle Eastern libraries, in $25 \%$ of Asian libraries and in $10 \%$ of Australian and New Zealand libraries. In all these regions therefore library staff had a role in some way with this regular emailing service.

However in $9 \%$ of African libraries and in $7 \%$ of both North American and European libraries, library staff were not involved in any way with this regular emailing service (or alternatively it could be the case that in some or all of these libraries the service was not offered to patrons).

\subsection{Regular newsletter for patrons}

Overall in only $31 \%$ of libraries did library staff manage the creation of a regular newsletter for patrons and in only $27 \%$ of libraries did library staff contribute to a regular newsletter. In $42 \%$ of libraries library staff were not involved in any way with the creation of a newsletter for patrons (or alternatively it could be the case that in some or all of these $42 \%$ of libraries the service was not offered to patrons).

\section{By type of library}

The creation of a regular newsletter for patrons was managed by library staff in $75 \%$ of government department libraries. This outreach service was also managed by 
library staff in $67 \%$ of research institute libraries, in $62.5 \%$ of law firm libraries, in $33 \%$ of Court libraries and in $21 \%$ of university law school libraries. Library staff contributed to this outreach service in all Bar / Law society libraries, in $26 \%$ of university law school libraries, in $25 \%$ of law firm libraries, in $22 \%$ of Court libraries, and in $12.5 \%$ of government department libraries. In these types of library therefore library staff had a role in some way with the creation of a regular newsletter for patrons.

However in $53 \%$ of university law school libraries, in $45 \%$ of Court libraries, in $33 \%$ of research institute libraries and in $12.5 \%$ of both government department libraries and law firm libraries, library staff were not involved in any way with this outreach service (or alternatively it could be the case that in some or all of these libraries the service was not offered to patrons).

\section{By region}

The creation of a regular newsletter for patrons was managed by library staff in $67 \%$ of Central and South American libraries. This service was also managed by library staff in $40 \%$ of Australian and New Zealand libraries, in $37.5 \%$ of Asian libraries, in $37 \%$ of North American libraries, in 33\% of Middle Eastern libraries, in $23 \%$ of European libraries and in $18 \%$ of African libraries. Library staff contributed to this outreach service in 55\% of African libraries, in 37\% of European libraries, in 33\% of both Central and South American libraries and Middle Eastern libraries, in $20 \%$ of Australian and New Zealand libraries, in $12.5 \%$ of Asian libraries and in $7 \%$ of North American libraries. In all these regions therefore library staff had a role in some way with this service.

However in $56 \%$ of North American libraries, in $50 \%$ of Asian libraries, in $40 \%$ of European libraries and Australian and New Zealand libraries, in 34\% of Middle Eastern libraries and in $27 \%$ of African libraries, library staff were not involved in any way with this regular newsletter for patrons service (or alternatively it could be the case that in some or all of these libraries the service was not offered at to patrons).

\subsection{Library social networking sites (e.g. Facebook or Twitter)}

Overall in only $34 \%$ of libraries did library staff manage the library's social networking sites and in only $21 \%$ of libraries did library staff contribute to the library's social networking sites. In $45 \%$ of libraries library staff were not involved in any way with the library's social networking sites (or alternatively it could be the case that in some or all of these $45 \%$ of libraries the service was not offered to patrons).

\section{By type of library}

The operation of the library's social networking sites for the benefit of patrons was managed by library staff in all Bar / Law society libraries. This service was also managed by library staff in $67 \%$ of research institute libraries, $40 \%$ of university law school libraries and $37.5 \%$ of government department libraries. Library staff contributed to the operation of these sites in $37.5 \%$ of law firm libraries and in $22 \%$ of university law school libraries. In these types of library therefore library staff had a role in some way with this outreach service for patrons.

However in all Court libraries, in $62.5 \%$ of government department libraries and law firm libraries, in $38 \%$ of university law school libraries and in $33 \%$ of research institute libraries, library staff were not involved in any way with this outreach service (or alternatively it could be the case that in some or all of these libraries the service was not offered to patrons). 


\section{By region}

The operation of the library's social networking sites was managed by library staff in $67 \%$ of Central and South American libraries and Middle Eastern libraries. This service was also managed by library staff in $50 \%$ of North American libraries, in $37.5 \%$ of Asian libraries, in $30 \%$ of European libraries and in $22 \%$ of Australian and New Zealand libraries. Library staff contributed to this outreach service in $45 \%$ of African libraries, in $23 \%$ of European libraries, in $17 \%$ of North American libraries, in $12.5 \%$ of Asian libraries and in $11 \%$ of Australian and New Zealand libraries. In all these regions therefore library staff had a role in some way with this service.

However in $67 \%$ of Australian and New Zealand libraries, in 55\% of African libraries, in $50 \%$ of Asian libraries, in $47 \%$ of European libraries and in $33 \%$ of North American libraries, Central and South American libraries and Middle Eastern libraries, library staff were not involved in any way with this service (or alternatively it could be the case that in some or all of these libraries the service was not offered to patrons).

\section{Conclusion}

Respondents were least likely to be involved in some way with the library's social networking sites, whilst they were most likely to be involved in some role with the regular emailing of information to patrons.

\section{Tailored services for specific patron groups}

Respondents were asked to identify the tailored services that were offered to specific patron groups. In total 122 libraries or $98 \%$ of respondents answered this question, and in the majority of these libraries (i.e. in 63\%) tailored services were offered to specific patron groups.

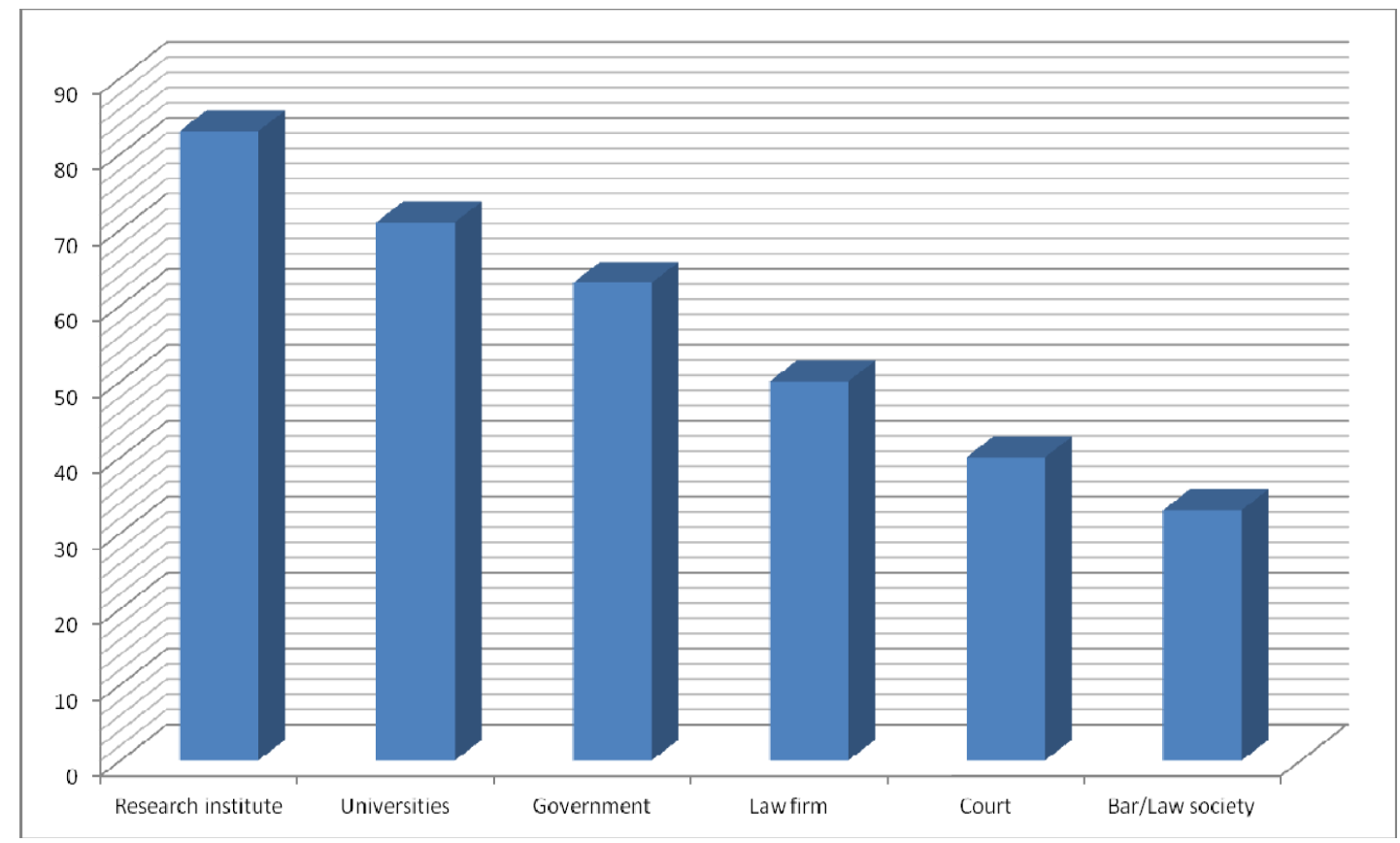

Graph 17: Percentage of libraries offering tailored services to their patrons

As the graph above shows, by type of library, $83 \%$ of research institute libraries offered tailored services. This was followed by $71 \%$ of university law school libraries, $63 \%$ of government department libraries, $50 \%$ of law firm libraries, $40 \%$ of Court libraries and $33 \%$ of Bar / Law society libraries. 
By region, $78 \%$ of North American libraries offered tailored services to specific patron groups. This was followed by $75 \%$ of Middle Eastern libraries, $67 \%$ of Central and South American libraries, $62 \%$ of African libraries, $57 \%$ of European libraries, $56 \%$ of Asian libraries and $50 \%$ of Australian and New Zealand libraries.

All university law school libraries in Central and South America offered tailored services. $80 \%$ of these libraries in North America, $75 \%$ of these libraries in Africa and the Middle East, $67 \%$ of these libraries in Australia and New Zealand and Asia, and $59 \%$ of these libraries in Europe provided tailored services.

\title{
Comments from libraries about their tailored services
}

Respondents were also asked to describe their tailored library services for specific patron groups. A full list of comments on library tailored services for different patron groups are listed by type of library in Appendix 11. Summaries for each type of library are provided below.

\begin{abstract}
University law school libraries
Members of faculty and postgraduate students were the two main patron groups identified as receiving tailored services in university law school libraries. According to one respondent, faculty services amounted to "doing everything they asked". This could include offering a dedicated research librarian for each tenured faculty member, targeted research, access to a pool of research assistants, regular meetings with faculty, one-to-one research skills appointments, current awareness services, unique access to specialised databases and electronic journals, books on extended loan or free scanned or photocopied articles delivered directly to the faculty desk, research guides for courses taught by faculty and customised alerts via RSS feeds. Some libraries also offered acquisition notifications and published an annual faculty publication bibliography. Tailored services for PhD and LLM students were more limited in scope and included offering one-to-one research skills appointments or dissertation clinics. One to one in-depth training or group training was also offered on using specific databases, the library print collections and electronic resources, the library catalogue and other indexes, creating bibliographies, the citing of legal authorities using national standards and avoiding plagiarism. Some library staff also taught advanced legal research classes for credits and reserved library study carrels for these students.
\end{abstract}

\section{Research institute libraries}

Far fewer comments received. One to one research sessions, advice on use of software and citation systems and current awareness services are mentioned. Some libraries offered free library carrels and free copying and printing for visiting fellows. One library offered a dedicated "Welcome Centre" for all new patrons that provided helpful advice for patrons new to the country, extensive library tours, encouragement of networking and pastoral care. Certain categories of visiting fellows could also be allocated a library carrel with free printing, a monthly stipend and given the opportunity to hire a flat attached to the institution.

\section{Court libraries}

Specialised services for judges and magistrates were offered including a research service and one-to-one appointments on specific topics on request.

\section{Government department libraries}

Tailored services included research assistance for members of staff undertaking taxation degrees, one-to-one sessions on legal databases for new solicitors, a regular "table-of-contents" service for specified legal journals, a specialised research service for parliamentarians, e-alert service, literature searches, journal routing, 
specially designed services for sight-impaired patrons and training for different client groups.

\section{Law firm libraries}

Includes one to one training for all lawyers and trainees, tailored to their practice areas, current awareness services, monitoring of cases and "after action" reviews.

\section{Bar I Law society libraries}

Includes research and advice sessions.

\section{Ambitions and future challenges}

Respondents were asked to identify and prioritise their three most important ambitions and future challenges. Summaries with examples of the three top choices for each type of library are provided below.

\section{University law school libraries}

1. Developing the library's electronic and digital resources:

For example reviewing collection development policies, shifting from print resources to electronic resources, cancelling looseleaf books, weeding under-used materials, subscribing to new databases and e-books, planning and implementing digitisation projects and improving the electronic dissemination of the table-of-contents of books and journals to users.

\section{Improving research skills training for patrons:}

For example offering classes in advanced legal research and international legal research, embedding library teaching in the academic programmes, developing online information literacy modules, redesigning legal research instruction, providing additional one-to-one research support sessions and facilitating webinars,

3. Refurbishment and better use of space to provide new patron services: For example creating dedicated postgraduate study areas, group study rooms, casual seating areas and quiet study areas. Also planning the relocation of dispersed law collections to one area in the law faculty building, and planning a new law library.

Other popular ambitions or future challenges included defending budgets, improving the marketing of the library's collections and services, making better use of social media to communicate with patrons, redesigning the library website and encouraging staff development.

\section{Research institute libraries}

1. Developing the library's electronic and digital resources:

For example expanding provision of e-books, expanding digital information sources and managing and updating the print and electronic collections.

\section{Refurbishment and better use of space to provide new patron services.}

Joint 3. i) Concerns about maintaining library budgets and ii) Improving research skills training for patrons.

\section{Court libraries}

1. Planning or completing digitisation projects.

2. Concerns about maintaining budgets or the implications of reduced budgets. In particular, worries about maintaining staffing levels faced with budget cuts. 


\section{Expanding electronic resources.}

\section{Government department libraries}

1. Service improvement priorities.

For example continuing to provide value-added services, improving the visibility and awareness of collections and maintaining high quality services whilst in temporary premises.

2. Concerns about maintaining budgets or the implications of reduced budgets.

3. Building expansion priorities.

For example planning a new landmark building, moving to a new building or enlarging the library.

\section{Law firm libraries}

1. Service improvement priorities.

For example adding value to the law firm, reviewing services, building or improving the Knowledge Management system, improving access to library resources, developing competitive business intelligence (e.g. increasing business, client and competitor information), and compiling specialised bibliographies.

2. Marketing the library and embedding it better within the work of the law firm teams. For example better branding of the library services and creating an app library.

3. Collection management issues.

For example managing the move from print to electronic format and obtaining lower costs on products from vendors.

\section{Bar I Law society libraries}

1. Collection management issues.

For example maintaining a high quality collection and fully exploiting electronic resources.

2. Keeping the library useful and relevant for members.

For example meeting the expectations of students.

3. Training patrons in research skills.

\section{Public libraries and Other libraries}

\section{Service improvement priorities.}

For example providing specific tailored information for all legal advisors, identifying all the personnel within the organisation, building and advertising a legal bibliographic database, educating patrons about copyright law, developing user-friendly services and ensuring services can be accessed by new technology such as tablets, mobiles and e-readers.

\section{Collection management issues.}

For example trying to maintain a responsive range of online law subscriptions, renegotiating e-subscription licences within rigid guidelines and integrating digital materials into a traditional library.

3. Concerns about maintaining budgets or the implications of reduced budgets. For example juggling ever decreasing funds and financing the integration of digital materials into a traditional library. 


\section{Final conclusions}

I hope very much that the comparative statistics, detailed analysis and additional library commentaries contained in this survey report will prove useful to the 124 major law libraries that kindly provided the questionnaire data and to other libraries too. I think the many research findings have illuminated the current research support services offered to law library patrons and have identified emerging trends in service provision. For the future, I hope the comparative benchmarking and best practice information contained in this report will help in some small way with encouraging major law libraries to develop their research support services and will assist them in highlighting the value of specialist legal information services.

\section{Acknowledgements}

I would like to thank Marci Hoffman (Associate Director, Berkeley Law Library, University of California) and Jules Winterton (Acting Director, Institute of Advanced Legal Studies, UK) for their invaluable help and advice in creating the survey questionnaire and to Michael Lindsey at the Berkeley Law Library for his practical help in making the survey questionnaire available on the web. I would also like to thank the IALL Board for their encouragement of this project. Much of the initial work on the shorter report to the IALL Board and this fuller published report was achieved whilst I was a Visiting Fellow at the Max Planck Institute for Comparative and International Private Law, Hamburg, Germany in September 2012. I would therefore like to thank the Library Director, Professor Dr Holger Knudsen, for providing the ideal research environment and wonderful hospitality during this key time. Finally my job has been made considerably easier by having Laura Griffiths (IALS Academic Services Librarian) calculate many of the statistics for the survey report using SPSS statistical software and I would like to thank her for her valuable assistance.

Appendices [available at: http://ials.sas.ac.uk/library/lawlibs/report.htm] Appendix 1: Survey questionnaire Appendix 2: A list of the libraries that completed the survey questionnaire Appendix 3: Most popular subscription databases Appendix 4: List of cancelled databases Appendix 5: Library involvement in digitisation projects Appendix 6: Library special collection and archive weblinks Appendix 7: Library comments on training opportunities for librarians Appendix 8: Library comments on web-based services Appendix 9: Most popular Library Management System Appendix 10: Library comments on outreach services Appendix 11: Library comments on tailored services for different types of patrons

DG

$28 / 5 / 13$ 